\title{
A DISCUSSÃO DO FUTURO CÓDIGO CIVIL (")
}

PROF. RUBENS REQUIÃO

Exm. ${ }^{\circ}$ Sr. Presidente Tancredo Neves.

Exmos. Srs. Deputados Membros da Comissão Especial.

Não dissimulamos, Sr. Presidente e Srs. Deputados, a nossa satisfação e honra de vir, perante esta douta Comissão Especial do Código Civil, participar, como professor da Universidade Federal do Paraná, dos trabalhos que visam à reelaboração de nosso Código $\mathrm{Ci}$ vil, oferecendo modesta contribuição.

\section{PARTE}

1. - De há muito vimos acompanhando os esforços do Governo em oferecer-nos uma legislação moderna, compatível com a nossa cultura e com o alto grau de desenvolvimento que, nas últimas décadas, logramos, graças ao trabalho fecundo do povo brasieliro. A vetusta legislação, seja o Código Comercial, seja o Código Civil, mais recente, reflete, como é natural, o grau de nossa civilização agrária de antanho. Mesmo assim, desejamos consignar nossa homenagem e admiração pelo gênio dos legisladores do Império e da Primeira República, que nos legaram, mercê de sua inteligência e cultura, dois monumentos de inexcedivel valor. Embora o decurso do tempo, ainda prestam eles expressivos serviços a nossa ordenação jurídica.

Evocamos, Senhores Deputados, o valor desses diplomas, para projetar a enorme responsabilidade de nossa geração, que se impõs a audaciosa e grave responsabilidade de substituir a atual codificação civil e comercial. A tarefa de modernizar as regras que determinam a conduta lícita dos cidadãos, com efeito, constitui obra de que não se pode descurar, tarefa não de um grupo ou de uma equipe

(*) Dissertação crítica ao Projeto de Lei n.० 634/75, apresentada, a convite da Comissão Especial da Código Civil, na Câmara dos Deputados, em sessão de 13 de agosto de 1975. 
de juristas, mas de toda uma Nação. Porisso, desde já, somamos nossa voz de cidadão a de tantas outras, inclusive as ouvidas no seio desta Comissão, de que a elaboração legislativa do novo Código Civil não deve ser pautada pela cadência acelerada, na aflição dos prazos regimentais, na obsessão da pressa das votações simbólicas. Felizmente, V.Excia. Sr. Presidente, em declarações prestadas recentemente à imprensa, para a tranquilidade de todos, reafirmou as intenções do Sr. Ministro da Justiça, de que "não é pensamento do governo pressionar o Congresso no estudo, debate e votação do novo Código" ("O Estado de São Paulo", 23 de julho de 1975).

A experiência do açodamento na tramitação de Leis, colhida nos últimos tempos, nos dá a triste visão de diplomas legais mal elaborados, que começam por não expor tecnicamente a matéria a que se propuzeram. Apontamos, como exemplos a não serem seguidos, a elaboração do Código de Propriedade Industrial, que está a afligir as nossas empresas, e que na verdade começou por destoar das Convenções !nternacionais (Convenção da União de Paris) a que expontaneamente aderimos, ao deixar fora de seu âmbito vários institutos importantíssimos, tais como o do "Nome comercial", o do "Títulos de Estabelecimento" e alguns outros. Prometeu-se para isso uma legislação especial que até agora estamos aguardando, com grande prejuízo para os interessados e para a ciência jurídica. $\mathrm{Na}$ verdade, aquele diploma constitui uma simples lei especial, pois se resume à disciplina da tutela dos direitos relativos às "Patentes" e "Marcas" não merecendo, porisso, o pomposo título de Código, que se the outorgou.

O mesmo se diga do Código de Processo Civil, que não honra o autor de seu Projeto, tais são as imprecisões e lacunas que contém. Pelo injustificado açodamento na sua tramitação nesta Casa, não houve tempo para a sua complementação. E assim mesmo foi promulgado, ficando excluido de seu âmbito precisamente matéria que necessita da mais urgente reelaboração, como a Ação do Despejo, a Ação Renovatória de Locação Comercial; a de Dissolução de Sociedades Comerciais e outras tantas. Lembremo-nos que logo após a promulgação de seu texto, incrivelmente, o Código de Processo sofreu correções, sendo necessário uma legislação para esse fim.

Os trabalhos desta douta Comissão, porisso, merecem ser desenvolvidos com serenidade e tranquilidade, sem precipitações, em respeito ao povo brasileiro, cuja vida cotidiana será pautada pelas regras que nessa Casa serão objeto de nova codificação.

Nosso propósito, Sr. Presidente e Senhores Deputados, neste 
depoimento que prestamos referente ao Projeto de Lei n. ${ }^{\circ} 364$, de 1975, é de circunscrever nossa apreciação crítica à Parte Geral, e aos Livros Primeiro e Segundo, respectivamente, consagrados às "Obrigações" e "à Atividade Negocial". Assim procedemos, devido ser esta matéria a de nossa predileção cultural, tanto na especialização da cátedra universitária como na banca profissional.

Desejamos aquí deixar patente nossa profunda ardmiração pela douta Comissão de juristas que elaborou e reviu o Projeto, que sem dúvida alguma representa um ponto alto de nossa cultura jurídica e do espírito público de seus redatores, cujo trabalho merece o respeito de nossa homenagem.

\section{O FRACASSO DA UNIFICAÇÃo}

2. - Antes, porém, de examinarmos especificamente os dispositivos do Projeto que consideramos passiveis de crítica e de aperfeiçoamento, pretendemos fixar nossa posição doutrinária relativamente a problema fundamental. Referimo-nos ao critério que prevaleceu, de unificação dos Códigos, fazendo-se com que o Código Civil absorva e regule, também, toda a matéria comercial.

Nossa crítica inicial, porisso, se dirige à estrutura básica do Projeto. A unificação de que se trata, como bem esclareceu o Coordenador da Comissão Revisora Prof. Miguel Reale, não é a do Direito Privado. Muita matéria privatista, com efeito, escapa de seu plano. Consiste a unificação, isto sim, na simples justaposição formal da matéria civil ao lado da matéria comercial, regulada num mesmo diploma. Constitui, repetimos, simples e inexpressiva unifição formal. Isso, na verdade, nada diz de científico e de lógico, pois, na verdade, como se disse em Exposição de Motivo preliminar, o Direito Comercial, como disciplina autônoma, não desaparecerá com a codificação, pois nela apenas se integra formalmente.

O artificialismo desse critério criou no Projeto a preocupação de proscrever o adjetivo "comercial". ou "mercantil". Essas expressões são tabus... As sociedades milenarmente conhecidas por sociedades comerciais se passa a inexpressivamente apelidar de "sociedades empresariais", e "a representação" secularmente designada por 'comercial", constrangedoramente fora de nossa línguagem do mercado, se chama de "agência". Ficamos, apenas, nestes dois significativos exemplos. Cria-se, inventa-se uma linguagem arbitrária aos nossos costumes, à nossa tradição, para ajustar a uma codificação irreal e artificiosa. 
Muito mais razoável e funcional seria se permanecessemos no sistema de codificação dualista, como nos projetos de 1965, inspirado no modelo suiço, de um Código Civil e de um Código de Obrigações, e não com o incômodo sistema colado dos italianos...

A evolução atual do Direito, é necessário que se tome tento, tem desanconselhado os sistemas unificados. Porisso ponderemos que a ciência jurídica de nosso País seria melhor servida se se limitasse, o futuro Código Civil, à Parte Geral, ao Direito de Família, ao Direito das Coisas e ao Direito das Sucessões. As Obrigações, estas sim, unificadas, sem distinção entre obrigações civis e comerciais como hoje ocorre, teriam um Código especial. A mercantilização das obrigações civis, como já observava o Prof. Inglez de Souza, no Projeto de 1912, não comporta o dualismo das regras obrigacionais. Lei especial, de natureza geral, disciplinaria as sociedades comerciais, inclusive as anônimas, num sistema moderno e global, bem como um diploma específico se destinaria à regulação moderna de todos os títulos de créditos, com base na legislação uniforme internacional.

Assim, as céleres transformações das sociedades comerciais e dos títulos de crédito não afetariam a permanente inteireza dos Códigos.

Tem-se sustentado, entretanto, e disso fez éco a Comissão Revisora, que o pensamento jurídico nacional propende, tradicional e historicamente, para a unificação, dita, impropriamente, do Direito Privado. E verdade que desde o "Esboço" de Teixeira de Freitas, nos meados do século passado, como o "Projeto", de 1912, de Inglez de Souza, a unificação dos códigos tem sido preferida. Não contestamos esse fato histórico.

O que desejamos contestar, entretanto, é que se assim foi outrora, os tempos modernos não só ditam, como impõem a fragmentação legislativa. A codificação foi um ideal de síntese, bem própria do idealismo do século passado, compatível com uma sociedade aparentemente estática e imóvel, de que foi Stuart Mill um dos mais convencidos enunciadores.

A sofreguidão do progresso e as transformações sociais rápidas, quando não violentas, atingindo a fundo as instituições jurídicas, fazem com que a unificação seja uma vã e ilusória pretensão.

Com efeito, dois exemplos de unificação apenas se apresentam aos nossos olhos: a Suiça, no século passado, unificou o Direito das Obrigações, tão somente; a arrogância e o orgulho fascista, na ltá- 
lia, impôs o Código Civil unificado, de 1942, abrangendo não só os preceitos de Direito Comercial como também os de Direito do Trabalho. Mas essa unificação se explicava pela preocupação ideológica e política do regime fascista, que via no comerciante um personagem ultrapassado do "decadente" mundo capitalista, sendo substituido pela figura da empresa, na qual se sobressai a participação do elemento trabalho. A unificação do direito privado alí, portanto, foi ditada por uma intenção declaradamente política e ideológica, sem natureza científica. O exemplo, porém, não prosperou.

Nas duas últimas décadas, a renovação legislativa no mundo ocidental não seguiu o inutil critério formal da unificação. Tomemos ao léu, alguns sugestivos exemplos, que merecem, estes sim, ser seguidos: a Alemanha Ocidental, em 1965 manteve a codificação dualista, reelaborando em lei especial modelar as sociedades anônimas revendo fragmentariamente outros institutos de direito privado; a França refez, inteiramente, em 1966, o direito societário, com sua moderna "Lei de Reforma das Sociedades Comerciais", e Portugal sancionou seu novo Código Civil e se adianta em estudos para rever o vetusto Código Comercial. Entre nossos visinhos sulamericanos, apontamos a Argentina, que refez há poucos anos atrás, seu Código Civil, sem revoga-lo, e promulgou uma Lei Geral das Sociedades; a Colombia, em 1971, surgiu com novo Código do Comércio, e o México se revela com excelente Lei Geral dos Títulos de Crédito e uma Lei Geral de Sociedades Comerciais.

Seria ocioso, e fastidioso, prosseguir nesta amostragem.

$\mathrm{Na}$ verdade, Senhor Presidente, a unificação dos Códigos já surgiu, entre nós, nati-morta. O Projeto, em várias oportunidades, se descarta da unificação e, mesmo da codificação, rementendo a regulação de certos institutos para "a lei especial", sem motivos de ordem técnica e regulamentar. Mas o que é mais grave e sintomático é que governos anteriores recomendaram à Comissão Revisora que fosse adotado o sistema unificado, e agora vem o mesmo governo, com absoluta franqueza, determinar que se retire do Projeto a regulação das sociedades anônimas. Por que apenas as sociedades anônimas e não também todas as sociedades comerciais?

Acompanhamos com curiosidade as positivas declarações e pronunciamentos do Ministério da Fazenda, em face de absoluta passividade e alheamento do Ministério da Justiça, pondo em destaque, fora do Projeto, as sociedades anônimas. Considera o Sr. Ministro da Fazenda que a matéria relativa a essas empresas constitui tema preponderantemente de natureza econômica, com vistas ao desenvolvimento nacional. Seu tratamento há de ser, portanto, segundo 
essa doutrina, mais tecnológico do que jurídico. Mas esqueceram as autoridades que o ordenamento jurídico é fundamental e básico para a segurança e garantia das instituições econômicas. Mas, enfim, foram as sociedades anônimas destacadas do Projeto, criando situação confiltante com o Projeto de Código Civil, como vamos analisar.

\section{A SUPERPOSIÇÃO DE PROJETOS}

3. - Com a retirada da matéria relativa às anônimas do Projeto, presenciamos a confirmação de nossa tese, de que o Direito moderno almeja uma legislação fragmentária, distribuida em vários Códigos especializados, como pregou sabiamente o Prof. Waldemar Ferreira. Após as sociedades anônimas, há de se legislar, também, em sentido de modernização, sobre o direito cambiário, que, em face das Leis Uniformes de Genebra, está a reclamar uma completa reelaboração. A isso se furtou o Projeto, remetendo a matéria para a "legislação especial".

Vejamos, então, o conflito que se estabeleceu entre o Projeto de Código Civil, surgido da área do Ministério da Justiça, com o Projeto de Lei de Sociedades Anônimas, do Ministério da Fazenda.

Quando, no início deste ano, nos foi dado opinar sobre o Anteprojeto de Lei de Sociedades Anônimas, no preâmbulo de nossas sugestões achamos de conveniência fixar o nosso pensamento. E dissemos: "Deixo aquí, inicialmente, registrado meu inconformismo em não termos, a exemplo da França e do México, uma lei geral de reforma, não só das sociedades anônimas, mas de todas as sociedades comerciais. Não tem sentido científico destacar as sociedades anônimas do futuro Código Civil unificado, e alí deixar enclausuradas as outras sociedades, pois elas também são instrumentos valiosos do desenvolvimento nacional, e estão a clamar por modernização".

Esse destaque das anônimas, criou sério embaraço e problemas que se refletem agudamente, em prejuízo do Projeto de Código Civil, no Livro da Atividade Negocial.

O Projeto de Código Civil, no Capítulo VIII, do Livro II, após tratar dos vários tipos de sociedades de pessoas, volta-se para a regulação das "Sociedades Ligadas" (Capítulo VIII), para a "Transformação, Incorporação e da Fusão das Sociedades" (Capítulo X), da "Sociedade Dependente de Autorização" (Capítulo XI), da Sociedade nacional e da sociedade estrangeira.

O Anteprojeto da Lei das Sociedades Anônimas regula, por sua vez; a mesma matéria, dando-lhe maior desenvolvimento no Ca- 
pítulo XXI, das Sociedades Coligadas, Controladoras e Controladas", e dopois da "Subsidiária Integral", do "Grupo de Sociedades" e do "Consórcio" etc.

Curioso é que o Projeto de Código Civil regula as sociedades em comanditas por açães, que estão ressurgindo no complicado mecanismo das empresas modernas, e o Anteprojeto das Sociedades anônimas também o faz.

E necessário, então, preliminarmente, decidir em que lugar deve essa matéria figurar, ou seja, se no futuro Código Civil ou na Lei de Sociedade por Ações.

A nós nos parece que, sendo a matéria de caráter geral, pois se refere não só às anonimas como também aos outros tipos de sociedades, merece ter sua colocação no Código Civil. Impõe-se, assim, um confronto, nesse particular, entre o texto do Projeto de Código Civil e o do das Sociedades Anônimas, pois um e outro têm preceiios que merecem acolhida. Seria aconselhavel, em consequência, que as duas Comissões autoras desses projetos se reunissem, a fim de, analisando e confrontando os preceitos, fundissem as duas opções numa só redação, a qual seria incluída no Código Civil, abstendose de ampliar a Lei de Sociedade Anônimas em matéria de ordem societária geral.

Há mais, porém. O Projeto de Código Civil deu grande amplitude aos preceitos disciplinadores das sociedades limitadas, pois procura aproximar sua estrutura da sociedade anônima fechada. A "Exposição de Motivos" do Projeto, nesse particular, enuncia o "minucioso tratamento dispensado à sociedade limitada, destinada a desempenhar função cada vez mais relevante no setor empresarial", e, por isso, "nessa linha de idéias, foi revista a matéria, prevendo-se a constituição de entidades de maior porte do que as atualmente existentes, facultando-se-lhes a constituição de órgãos complementares de administração, como o Conselho Fiscal, com responsabilidades expressas, sendo fixados com mais amplitude os poderes da assembléia dos sócios".

Ora, a existência de órgãos semelhantes aos da sociedade anônima, nas sociedades limitadas, aquelas reguladas em lei especial e estas constantes do Código Civil, importou em tratamento diferente entre os de uma e os de outra, embora esses órgãos, numa e noutra sociedade tenham a mesma natureza jurídica. É preciso, pois, uma completa revisão entre os preceitos das sociedades limitadas, do Código Civil, e os das sociedades anônimas, da lei específica. Apontamos, para exemplo, da reelaboração necessária dessa matéria, no 
círculo das sociedades limitadas, no texto do Código Civil, os seguintes casos:

Em relação ao Consehlo Fiscal: deixar, bem claro, quanto às sociedades limitadas, que o órgão seja de criação facultativa no contrato social. Convém porém estabelecer que a sociedade, tendo maior número de sócios, mais de 15 , por exemplo, apenas tenha existência obrigatória. Convém valorizar, como fez o Projeto da Lei de sociedades anônimas, (Art. 117, § $3^{\circ}$ ) a remuneração dos conselheiros para não se tornar um órgão ineficaz, como engodo aos direitos dos sócios dissidentes.

Em relação às Assembléias Gerais: a disciplina das assembléias dos cotistas deve ser semelhante ou aproximada a das sociedades anônimas; deve-se por exemplo, permitir que o sócio seja representado na A.G., não só por sócio e por advogado (como prevê o artigo $1.110, \S 10^{\circ}$, do Projeto de Código Civil), mas também por membro da administração, já que a limiłada pode admitir diretores não sócios. Não há motivo, por igual, que se impeça que o economista ou administrador de empresa, com curso superior, não possa comparecer à assembléia como mandatário de cotista, ou comparecer para assesora-lo nos debates.

Enfim, há necessidade de um prolongado e detalhado confronto entre textos, a fim de que a Assembléia Geral das limitadas se aproxime, tanto quanto possível, das assembléias das anônimas.

\section{O PROBLEMA dOS TítUlOS DECRÉdito}

$4 .^{\circ}$ - E curioso e merece ser assinalado em relevo especial, a diferente técnica do Projeto em relação à regulação dos títulos de crédito. Aquí se repele, no texto do Projeto, o ordenamento específico dos títulos cambiários e dos que a ele se assemelham, para se cingir apenas ao esboço de preceitos gerais. Precisamente o contrário do que se fez em relação às sociedades comerciais, onde cada uma delas mereceu do Projeto um tratamento minucioso e específico. Isso demonstra a falta de unidade técnica na estruturação do Projeto...

Tanto quanto as sociedade comerciais os títulos de crédito estão, a partir da letra de câmbio, da nota promissória e do cheque, clamando por reelaboração legislativa. Há uma década vimos protestando contra a balbúrdia, imprecisões e confusões que se estabeleceu no direito brasileiro em relação a esses instrumentos de crédito.

Duas legislações os servem, desde que foram introduzidas como Direito interno as chamadas Leis Uniformes de Genebra, sobre le- 
tras de câmbio, notas promissórias e cheques, convenção internacional da qual o Brasil participou e subscreveu. A exemplo do que ocorreu na Alemanha, França, Itália e Portugal, inclusive o Japão, aderentes àquela Convenção, ao lado de mais trinta países, não se reelaborou entre nós novo diploma nacional, mas apenas se decretou o seu atendimento como lei interna. Isso acarretou uma dupla legislação, pois a Lei Cambial de 1908 e a Lei do Cheque de 1912 não foram de todo revogadas, pois muitos dispositivos das Leis Uniformes sofreram "reserva" do governo brasileiro. Constitui uma tortura para os estudantes, advogados e juizes, o manuseio da complexa legislação, para encontrar o preceito adequado à solução da questão jurídica.

Valemo-nos desta tribuna, Sr. Presidente, para reclamar das autoridades públicas a atenção para esse cruciante problema, e para sugerir que, mantendo-se no Projeto a disciplina específica das sociedades comerciais, o mesmo tratamento se dê aos títulos de crédito, regulando cada uma de suas espécies, sobretudo a letra de câmbio, a nota promissória, o cheque e a duplicata de fatura. Esse comportamento constitui um imperativo do sistema de codificação que se adotou, e, mais do que isso, uma imposição de simetria, pois os critérios de tratamento dos institutos jurídicos no Projeto devem ser um só.

Lembramos, nesse propósito, que o Projeto de Código de Obri-

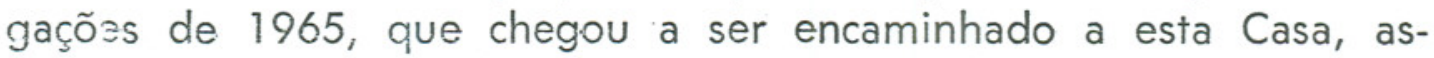
sim tratava da matéria, regulando minuciosamente tanto as sociedades comerciais, como os títulos de crédito. Nossa opinião, entretanto, como anteriormente acentuarmos, propende para regulação das sociedades e dos títulos de crédito em disciplinas especiais, a exemplo da legislação mexicana e argentina cujos virtudes proclamamos.

Mas, examinando-se o Projeto vemos que, na Parte Especial, do Livro I, das Obrigações, o Título VIII, disciplina basicamente os Títulos de Crédito. Essas "Disposições Gerais" merecem a nossa mais candente crítica, por abandonarem os princípios que regem as Convenções de Genebra, a que acima nos referimos.

Todos os bachareis sabem, e é ensinamento comezinho nos cursos jurídicos, que a letra de câmbio constitui, entre os títulos, o mais perfeito de todos. E assim é pela experiência quase milenar na manipulação desses utilissímos instrumentos de crédito, que, tendo surgido no comércio internacional da moeda, foram no século VXIII apropriados pelas legislações nacionais. No século passado idealismo de internacionalistas da Escola de Gand, levantou a tese de 
que tais títulos de crédito deveriam retornar à sua disciplina internacional, propondo-se a elaboração de uma legislação uniforme, por uma Convenção internacional. A Convenção de Haia chegou a esboçar essa pretensão dos povos, mas foram os trabalhos frustrados pela Primeira Grande Guerra. Após, com o patrocínio decidido da Liga das Nações, os esforços dos internacionalistas se consagraram em 1930e 1931. O Brasil participou das sessões e subscreveu a Convenção, que foi ratificada e promulgada por esta Casa, ha cerca de dez anos.

Nada mais curial e lógico, portanto, do que se adotar como base, do Direito relativo aos títulos de crédito, os princípios uniformes internacionais, que já vigem no País. $E$, no entanto, assim não age o Projeto. Confessemos, senhores deputados, que não pudemos atinar porque se dará aos títulos de crédito um duplo tratamento, pois as regras codificadas no Projeto se divorciam, como logo apontaremos, da legislação cambiária.

Com efeito, o art. 939 do Projeto reza:

"Salvo disposição diversa em lei especial, regem-se os títulos de crédito pelo disposto neste Código".

Ora, ao que sabemos, todos os títulos de crédito existentes no Direito brasileiro, que enumeramos em 26, em nosso "Curso de Direito Comercial", se filiam, por remissões expressas, à disciplina da legislação cambiária. Por isso Pontes de Miranda apelidou todos esses títulos assemelhados à Letra de câmbio de "títulos cambiariformes". Lembro, com efeito, que assim é na Lei das Duplicatas, n. ${ }^{\circ}$ 5.474, de 1968; nos títulos rurais, em número de seis, no Decretolei n. ${ }^{\circ} 167$, de 1.967 , e tantas outros. Toda a legislação especial faz remissão, repetimos, à Lei Cambial n. ${ }^{\circ} 2.044$, de 1908, hoje alterada pela Lei Uniforme de Genebra. Todos esses títulos, portanto, não seguirão a disciplina do Projeto, que ficará assim vazio de significado prático.

A regra, pois, generalizada em nosso direito, é de que a lei cambial serve de lastro jurídico para os títulos de crédito especiais mais difundidos em nosso país.

Por que, então, estabelecer uma dupla feição para os títulos de crédito, deixando uns modelados pela lei cambiária, isto é, pela Lei Uniforme de Genebra, e outros por normas desnecessariamente diferentes, regidas pela lei civil? O Projeto não foi elaborado sob o signo, da unificação? Por que, insistimos, estabelecer em relação aos títulos de crédito uma insuportável dicotomia: - para umas espé- 
cies segue-se a disciplina do direito cambiário: para outras a do Projeío? Nuns títulos, por exemplo, permitir-se-ia a inserção da cláusula de juros (Lei Uniforme), para outros não se admitiria a mesma cláusula (Lei civil)?

Insistimos, portanto, na subordinação dos títulos de crédito às regras das Convenções genebrinas, que são modernas, práticas e universais. Isso não impedirá, naturalmente, que em casos específicos a lei que regular determinado título estabeleça regras diferentes, devido as suas peculiaridades.

Passamos a indicar alguns preceitos do Projeto conflitantes com os da Lei Uniforme cambiária.

\section{A - PROJETO}

Art. 925. Deve o título de crédito conter a data de emissão, a indicação precisa dos direitos que confere, e, por último, a assinatura do emitente.

$\S 10^{\circ}$ - É a vista o título de crédito que não contenha indicação do vencimento.

$\S 2 .^{\circ}$ - Considera-se lugar de emissão e de pagamento, quando não indicado no título, o domicílio do emitente.

\section{- LEI UNIFORME}

Art. 2. O escrito em que faltar alguns dos requisitos indicados no artigo anterior não produzirá efeito como letra, salvo nos casos determinados nas alíneas seguintes:

A letra que não indique a época do pagamento entende-se pagável à vista.

$\mathrm{Na}$ falta de indicação especial, o lugar designado ao lado do nome do sacado considera-se como sendo o lugar do pagamento, e, ao mesmo tempo, o lugar do domicílio do sacado.

A letra sem indicação do lugar onde foi passada considera-se como tendo-o sido no lugar designado, ao lado do nome do sacador.

\section{B - PROJETO}

Art. 926. Consideram-se não escritos no título a cláusula de juros, a proibitiva de endosso, a excludente de responsabilidade pelo pagamento ou por 
despesas, a que dispense a observância de termos e formalidades prescritas, e a que, além dos limites fixados em lei, exclua ou restrinja direitos e obrigações.

\section{- LEI UNIFORME:}

Art. 5. Numa letra pagável à vista ou a um certo termo de vista, pode o sacador estipular que a sua importância vencerá juros. Em qualquer outra espécie de letra a estipulação de juros será considerada como não escrita.

A taxa de juros deve ser indicada na letra; na falta de indicação, a cláusula de juros é considerada como não escrita.

Os juros contam-se da data da letra, se outra não for indicada.

Art. 15. O endossante, salvo cláusula em contrário, garante tanto da aceitação como do pagamento da da letra.

O endossante pode proibir um novo endosso, e, neste caso, não garante o pagamento às pessoas a quem a letra for posteriormente endossada.

Art. 46. O sacador, um endossante ou um avalista pode, pela cláusula "sem despesas, "sem protesto", ou outra cláusula equivalente, dispensar o portador de fazer um protesto por falta de aceite ou falta de pagamento, para poder exercer os seus direitos de ação.

\section{C - PROJETO}

Art. 955. O pagamento de título de crédito, que contenha obrigação de pagar soma determinada, pode ser garantido por aval.

Parágrafo único. É vedado o aval parcial.

\section{- LEI UNIFORME:}

Art. 30. O pagamento de uma letra pode ser no todo ou em parte garantido por aval.

\section{D - PROJETO}

Art. 957. O avalista se equipara àquele cujo nome indicar; na falta de indicação, ao emitente ou devedor final ............. 


\section{- LEI UNIFORME}

Art. 31. O aval deve indicar a pessoa por quem se dá. Na falta de indicação, entender-se-á ser pelo sacador.

Ademais a Lei Uniforme, é completa em relação à regulação do endosso tardio, em norma que o Projeto desconhece.

Afora os embaraços na escolha da norma adequada para aplicação ao caso concreto, imaginemos os percalços para os estudantes, ao se depararem, no confronto do futuro Código, com a legislação cambial, e as dificuldades didáticas que enfrentarão os professores, nesse inexplicável duatismo jurídico. Em relação aos empresários, então, a confusão seria imperdoável.

Impõe-se, assim, Sr. Presidente, a revisão completa do Título VIII, do Livro I, para harmonizar seus preceitos com os princípios já consagrados em nosso Direito e no Direito dos povos.

\section{AS MULTINACIONAIS E O PROJETO}

$5 .^{\circ}$ - Ao tratar de asunto relativo às empresas, o Projeto não poderia desconhecer, como ocorreu, do problema atual das atividades das multinacionais, no país.

Desejamos deixar claro, Sr. Presidente, nossa posição anti-xenofoba, pois sustentamos a conveniência e necessidade da participação das empresas multinacionais, através de seus capitais e transferência de tecnologia, no desenvolvimento nacional. Mas pensamos que essa atividade deva ser desenvolvida com os próprios recursos dos capitais alienígenos, não concorrendo essas empresas às fracas fontes de crédito de nosso modesto sistema financeiro. É necessário, portanto, comprender que é inconveniente a concessão da nacionalidade brasileira às subsidárias dessas empresas, constituidas no país, segundo a lei brasileira. $O$ que determina a nacionalidade das empresas, no mundo capitalista atual, não é a sua organização em determinado território, segundo tal lei; mas, o centro das decisões da política econômica da empresa é que the dá a real nacionalidade.

Outorgar-se a nacionalidade brasileira a empresa multinacional, que se instala no país não com sucursais, mas com empresa filiada, constituida no Brasil, segundo a legislação brasileira, é ingênuo irrealismo... 
A atual Lei de Sociedades Anônimas adota o critério de atribuição de nacionalidade na forma exposta no Projeto, isto é: "São nacionais as sociedades organizadas na conformidade da lei brasileira e que tem no País a sede de sua administração". Esse princípio é o mantido pelo Projeto, no art. 1.160:

"E nacional a sociedade organizada de conformidade com a lei brasileira e que tenha no País a sede de sua administração".

Difícil se apresenta, é verdade, a verificação exata da autonomia da administração local. As empresas multinacionais, organizando sociedades "brasileiras", subsidiárias, fazem constar de seus estatutos a forma de administração, nominalmente local, mas via de regra são geridas por simples "gerentes profissionais", designados pelo autoritário centro de decisões no exterior.

Muitos setores da administração pública percebem essa realidade, e excluem tais empresas "brasileiras" da concessão de certos favores ou incentivos oficiais. Esse desajuste entre a lei e a realidade dos fatos necessita ser corrigido.

Convém registrar que o Anteprojeto de Lei das Sociedades Anônimas, recentemente divulgado, no art. 109, coincide literalmente com o preceito do Projeto de Código Civil.

Em face dessas circunstâncias, e (já haviamos representado à douta Comissão de Inquérito desta Casa, que investiga as atividades das empresas multinacionais no País, presidida pelo eminente Deputado Alencar Furtado), é necessário que se dê flexibilidade ao preceito de nacionalidade, permitindo-se que leis específicas abandonem o critério legal e tradicional de nacionalidade para considerar estrangeira a empresa que, embora constituida segundo a lei brasileira, comprovada ou dissimuladamente tenha seu efetivo centro de decisão no exterior .

\section{AS PREFERÊNCIAS E OS PRIVILÉGIOS CREDITÓRIOS}

6. - O Projeto, em linhas gerais, talvez inadvertidamente, reproduziu quasi na íntegra, o Título XI, do Livro das Obrigações, arts. 1.554 , a 1.571, do Código Civil vigente. Consta a matéria, no Projeto, dos arts. 991 a 1.002.

A classificação das preferências está hoje totalmente subvertida, por uma dezena de leis especiais que deram nova feição ao quadro de preferências e privilégios creditícios. Haja vista, por exem- 
plo, no Projeto, que "o crédito pelos impostos devidos à Fazenda Pública, no ano corrente e no anterior" goza de privilégio geral (artigo 1.001, inciso VI).

Ora, o Código Tributário Nacional, Lei n. ${ }^{\circ} 5.172$, de 25 de outubro de 1966, no art. 186, estabelece que "o crédito tributário prefere a qualquer outro, seja qual for a sua natureza ou o tempo da constituição deste, ressalvados os créditos decorrentes da legislação do trabalho". Como se vê, o artigo do atual Código Civil está revogado, mas assim mesmo foi reproduzido no Projeto.

É necessário que o Título $X$, do Livro II, seja totalmente revisto, a fim de que as preferências e privilégios se ajustem, em seu elenco, às leis sociais e fiscais que hoje proliferam e dão tratamento especial a certos créditos.

A matéria é a mesma de que trata a Lei de Falências, cujo quadro de classificação de créditos foi afetado precisamente pelas leis fiscais e sociais que hoje imperam em nosso direito. O Código Civil futuro, coerente com a realidade, não pode permanecer cinqüenta anos atrazado, nessa matéria...

Permitimo-nos, para facilitar a empostação desse problema, reproduzir em síntese o resultado de nossas pesquisas no Direito vigente, em matéria de preferência e privilégios, que oferecemos em nosso recente CURSO DE DiREITO FALIMENTAR, (edição Saraiva, .. 1975). Nesse livro esclarecemos:

"Resta-nos, pois, compulsando a legislação em seu estado atual, modernizar o esquema da classificação dos créditos, apresentado naquele dispositivo de lei.

É o seguinte.

1. - Crédito resultante da indenização por acidentes do trabalho (Dec. lei n. ${ }^{\circ} 7.661$, art. 102, n. ${ }^{\circ} 7.661$, 21-6-1945).

2. ${ }^{\circ}$ - Créditos do salários dos empregados e de um terço da indenização trabalhista (CTN, Lei n. ${ }^{\circ} 5.172$, de 25-10-1966, art. 186; CLT, art. 499, § 1.; e Dec. Lei n. ${ }^{\circ}$ 192, de 24-2-1967).

3. - Créditos tributários da União, Estados e Municípios, no mesmo piano de igualdade (art. 60, parág. único, do Dec. lei n. ${ }^{\circ} 960$, de 17-11-1938, artigos 186 e 187, da Lei n. ${ }^{\circ}$ 5.172, de 25-10-1966 e Emenda Const. n. 1 , Art. $\left.9 .^{\circ}, 1\right)$. 
$4 .^{\circ}$ - Créditos parafiscais, tais como contribuições do INPS, SESC, SESI, SENAC, SENAI, etc., no mesmo plano que os créditos tributários da União.

5. - Créditos por encargos da massa (art. 124, § $1 .^{\circ}$, da Lei de Falências).

6. ${ }^{\circ}$ - Créditos por dívidas da massa (art. 124, § $20^{\circ}$, da Lei de falências).

7. - Créditos com direitos reais de garantia.

8. ${ }^{\circ}$ - Créditos com privilégio especial sobre determinados bens.

$9 .^{\circ}$ - Créditos com privilégios geral.

$100^{\circ}$ - Créditos quirografários.

(ob. cit., pg., 277, n. ${ }^{\circ}$ 258).

Lembramos que o novo Código de Processo Civil deu um tratamento mais minucioso ao antigo processo de Concurso de Credores, a que chama de Insolvência Civil, aproximando-o da Falência. É necessário, portanto, que o Código Civil apresente um elenco de privilégios e preferências que diga respeito tanto ao processo de insolvência civil como ao da falência.

Em consequência dessa realidade consideramos imperiosa uma total revisão do Projeto, nesse particular, a fim de se ajustar à legislação vigente que trata da matéria.

\section{PARTE}

7 - Esgotadas as nossas considerações gerais em relação ao Projeto, nos seus dois primeiros Livros, voltamo-nos agora para a análise de alguns preceitos específicos, que nos merecem reparos.

Preferimos, Sr. Presidente, nos ater às questões de fundo, de maior substância e gravidade, isentando-nos de observações de ordem formal, como as de redação. Muitas expressões, e modismos de linguagem, chegaram a ferir-nos os ouvidos, por sentirmos inadequados em documento de tão alta relevância. Deixamos, porém, estas questões ao critério da Comissão de Redação Final, desta Casa, que naturalmente louvar-se-á na sabedoria dos gramáticos e estilistas.

As observações específicas não são excessivas. Já haviamos apresentado sugestões à Comissão Revisora, por ocasião dos deba. 
tes sobre o Anteprojeto, e muitas delas foram aceitas, já incorporadas no texto. De acurada leitura do Projeto, surgem-nos novas questões, que aqui propomos, para a consideração desta doutra Comissão.

\section{O ABUSO DA PERSONALIDADE JURÍDICA}

(Art. 48). Uma das contribuições positivas que apresntamos, junto à Comissão Revisora, aceita desde o Anteprojeto, foi a inclusão no Código de norma coibitiva do desvio do uso da personalil dade jurídica, isto é, o mau uso da personificação jurídica. Ao fazelo, porém, a Comissão Revisora lhe deu um tratamento que não se comparibiliza com a pureza e elegância da doutrina da desisłimą̧ão da personalidade jurídica. Apresentando nova sugestão, foram elas em parte aceitas, resultando o texto atual do art. 48, que pomos em destaque.

"A pessoa jurídica não pode ser desviada dos fins estabelecidos no ato constitutivo, para servir de instrumento ou cobertura à prática de atos ilícitos, ou abusivos, caso em que poderá o juiz, a requerimento de qualquer dos sócios ou do Ministério Público, decretar a exclusão do sócio responsável, ou, tais sejam as circunstâncias, a dissolução da entidade.

Parágrafo único. Neste caso, sem prejuízo de outras sanções cabíveis, responderão, conjuntamente com os da pessoa jurídica, os bens pessoais do administrador ou representante que dela se houver utilizado de maneira fraudulenta ou abusiva, salvo se norma especial determinar a responsabilidade solidária de todos os membros da administração".

Permita-se-nos uma breve exposição da moderna doutrina, que se pretende introduzir no Código, pois não tem correspondência no vigente Código Civi. Conslitui, efetivamente, uma expressiva novidade, em nossa futura codificação.

É possível que se use a personificação de sociedades, sobretudo das sociedades comerciais, para burlar o direito dos credores. Se uma pessoa transferir para uma sociedade todo o seu patrimônio, este passa a the pertencer, como todos sabem. A manobra, como se vê, pode se tornar conveniente, desde que assegure o devedor malicioso o controle absoluto dessa entidade.

Nessas condições a personalidade jurídica forma um escudo, um 
"véu" como dizem os juízes norte-americanos, que construiram jurisprudencialmente a doutrina, sob o título de "disregard doctrine". Cabe, ao juiz, seguindo os preceitos da equidade e da justiça, penetrar esse "véu", "desconsiderando" a personalidade jurídica, para alcançar os bens, o patrimônio do devedor, que atrás da personificação da empresa se disfarçou...

Essa doutrina, sustentamos em conferência acadêmica, não é incompatível com os postulados do Direito brasileiro atual, pois é carregada de forte conteúdo ético. Apontamos decisões de nossos tribunais, em que analisamos a dificuldade de se coartar a fraude a credores, com o uso abusivo da personalidade jurídica de sociedades desviada de seus justos fins. A doutrina, admite e recomenda que nesse caso, comprovado o mau uso que o sócio fez da personificação da sociedvade, o juiz desconsidere a personalidade jurídica, penetrando no seu "âmago" para colher os bens ali encontrados, que constituem a garantia natural dos credores.

A verdade original da doutrina é que, ao penetrar na personalidade jurídica, desestimando-a, o juiz não anula a sociedade, que continua normalmente suas atividades, apenas desfalcada dos bens do sócio fraudulentamente nela incorporados.

O Anteprojeto havia dado solução diferente, determinando a dissolução da sociedade. Mas isso, como contraditamos na ocasião, importava em punir os demais sócios, que não deviam responder pela truculência e fraude do sócio atingido. Não seria justo. A Comissão, porém, embora meihorando o texto, não acolheu a doutrina em toda a sua pureza, pois pressupõe a ação do Ministério Público ou dos demais sócios. Não é essa a questão. A parte interessada, e legitimada para pleitear a penetração do juiz na personalidade jurídica, não é o Estado; nem os sócios, mas tão somente o credor.

Os credores particulares do sócio, despido de seu patrimônio, que foi transferido para a pessoa jurídica, fora do alcance deles, é que se apresentam como a parte legítima para pedir ao juiz que mande apreender os bens, constitutivos da garantia natural.

O problema não é de direito público ou de ordem pública. Não se pretende, com a teoria, dissolver punitivamente a sociedade. 0 Ministério Público não deve intervir numa questão extremamente privatista, como as relações entre devedor e credor. Nem os sócios, que são terceiros na pendenga creditícia. Cabe esse direito, tão somente ao credor insatisfeito, despido das garantias naturais que o patrimônio do devedor confere. 
Porisso insistimos que se acolha a doutrina em toda a sua pureza original, que pensamos ter traduzido na seguinte emenda, ou outra equivalente.

Emenda ao art. 48:

"A pessoa jurídica não pode ser desviada dos fins que determinam a sua constiôuição, para servir de instrumento ou cobertura à prática de ałos ilícitos ou abusivos de sócio. Neste caso, o juiz desconsiderando a exisrência da personalidade jurídica, a pedido do credor do sócio, poderá permîîr a efetivação de sua responsabilidade sobre os bens incorporados na sociedade para a sua paríicipação no capital social'.

7.2 - Caso fortuito e força maior. Art. 391) A doutrina nacional desautoriza a distinção, quanto aos seus efeitos entre "casos fortuito" e "força maior", na inexecução das obrigações. São consideradas juridicamente expressões equivalentes.

Clovis Bevilaqua, ao comentar o parágrafo único do art. 1.058, esclareceu o problema conceitual das duas figuras, nesta expressiva lição: "Conceitualmente o caso fortuito e a força maior se distinguem. O primeiro, segundo a definição de Huc, é "o acidente produzido por força física ininteligente, em condições que não podiam ser previstas pelas partes". A segunda, é "o fato de terceiro, que criou, para a inexecução da obrigação, um obstáculo, que a boa vontade do devedor não pode vencer". Não é, porém, a imprevisibilidade que deve, principalmente, caracterizar o caso fortuito, e, sim, a inevitabilidade. E, porque a força maior também é inevitável, juridicamente, se assimilam estas duas causas de irresponsabilidade. Uma, seca extraordinária, um incêndio, uma tempestade, uma inundação, produzem danos inevitáveis. Um embargo de autoridade pública impede a saida do navio do porto, de onde ia partir, e esse impedimento tem por consequência impossibilidade de levar a carga ao porto do destino. Os gêneros que se acham armazenados para ser entregues ao comprador são requisitados por necessidade da guerra. Nesses e em outros casos, é indeferente indagar se a impossibilidade de o devedor cumprir a obrigação procede de força maior ou de caso fortuifo. Por isso, o Código Civil reuniu os dois fatos na mesma definição: o caso fortuito ou de força maior é o fato necessário, cujos efeitos não era possível evitar ou impedir" (Cod. Civ. Com. Vol. 4, pág. 221).

A respeito da aplicação do preceito, relativo à conceituação do caso fortuito "e da força maior", verificamos que o Projeto repetiu 
- art. 1.058 do Código Civil, mas cancelou o seu parágrafo único, definidor daquelas hipóteses. Dispõe, apenas, no art. 391, que:

"O devedor não responde pelos prejuízos resultantes de caso fortuito, ou força maior, se expressamente não se houver por ele responsabilizado".

O parágrafo único, do art. 1.058, do atual Código Civil, dispõe:

"O caso fortuito, ou de força maior, verifica-se no fato necessário, cujos efeitos não era possível evitar ou impedir".

Verificamos, no decorrer da leitura do Livro I, das Obrigações, do Projeto, que muitos preceitos se referem à exoneração do obrigado, invocando a "força maior" junto ao "caso fortuito". Em alguns casos somente se invoca o "caso fortuito" e em outros apenas a "força maior". Tivemos a cautela de verificar que o atual Código Civil em várias artigos assim também procede.

No Projeto se alude isoladamente apenas ao "caso fortuito" nos artigos 490, 676, $\S 10^{\circ}, 898,904$ e 972; refere-se somente à "força maior" nos arts. 705, 711, 728, 734, 744, 742, 759. Em alguns outros as expressões estão juntas, como nos arts. 592, 585, 634, 651 .

Ora se não existe diferença técnica entre o caso fortuito e força maior, parece-nos de melhor alvitre, para assegurar a isenção de responsabilidade do devedor, que em todos os casos deveria o Projeto aludir tanto ao "caso fortuito" como "a força maior".

Tomemos alguns exemplos, para melhor elucidar nosso pensamento:

O art. 490 dispõe que "até o momento da tradição, nos contratos de compra e venda, os riscos da coisa correm por conta do devedor" e os do preço por conta do comprador"; o parágrafo único esclarece:

"Todavia, os casos fortuilos, ocorrentes no ato de contar, marcar, ou assinalar coisas,... correrão por conta do comprador". Pergunta-se, então, se no ato de contar, pesar e medir ocorrer um caso de "força maior", isto é, o fato de terceiro, os riscos da tradição correrão por conta do vendedor? Ora, tanto o caso tortuito como a força maior devem ter, na hipótese, o mesmo efeito.

Outro caso. Tomemos o art. 705. Diz esse preceito, relativo ao contrato de "comissão", que "por qualquer prejuízo que, por ação 
ou omissão, ocasionar ao comitente, responderá o comissário, salvo motivo de força maior". Se ocorrer um prejuízo, ocasionado não por motivo humano (força maior) mas por motivo da natureza (caso fortuito). a responsabiildade do comitente se modifica?...

Um estudo mais aprofundado dos preceitos que envolvem as figuras do "caso fortuito" e "força maior" talvez aconselhem, com mais propriedade, a aplicação em todos os textos a fórmula unitária de "caso fortuito, ou de força maior". Dá-se, assim, melhor clareza e maior amplitude à irresponsabilidade do obrigado ou do ocntrante, nas hipóteses previstas.

7-3 - Preferência dos varões sobre as mulheres. Em pleno "Ano Internacional da Mulher", patrocinado pelas Nações Unidas, para varrer da face da terra os preconceitos quanto à fragilidade e inferioridade das mulheres, princípio já repudiado pelo atual Código Civil, em sua última reforma, assistimos o Projeto consagrar preceito em que "os varões preferem às mulheres" (sic).

O art. 24, dispondo sobre a curadoria dos bens do ausente, $\S 2 .^{\circ}$, na falta do cônjuge, de pai, de mãe, caberá a descendente, o $\S 2 .^{\circ}$, determina que "entre os descententes, os mais vizinhos precedem aos mais remotos, e, entre os do mesmo grau, os varões preferem às mulheres". Por que? Mais razoável seria deixar a escolha ao prudente arbítrio do magistrado, que ajuizará da idoneidade dos pretendentes, pois não raras vezes as mulheres têm demonstrado maior zelo e habilidade na administração de bens alheios, do que os varões...

7.4 - Prescrição do cheque (omiriida). A segunda Convenção de Genebra, de 1931, introduzida em nosso. Direito interno pelo Decreto n. ${ }^{\circ}$ 57.595, de 1966, instituiu a Lei Uniforme do Cheque, que dispõe no art. 52: "Toda a ação do portador contra os endossantes contra o sacador ou contra os demais coobrigados prescreve decorridos que sejam seis meses, contados do termo do prazo de apresentação".

O Projeto não preve prazo prescricional de seis meses, pois os inicia de um ano. Assim, omitiu a prescrição de cheque, muito embora no att. 204, $\S 3 .^{\circ}$, inciso VIII, declare a prescrição em tres anos da "pretensão para haver o pagamento de tí́tulo de crédiòo, a contar do vencimento, ressalvadas as disposições de lei especial".

Ora, a doutrina comercialista ainda não fixou precisamente 0 cheque como título de crédiło. Sendo, por definição, uma ordem de pagamento à vista, uma pleiade de juristas lhe nega a qualidade de 
título de crédito. Impõe-se, assim, uma menção especial a esse documento, a fim de esclarecer que a "prescrição do cheque é de seis meses, da época de sua apresentação". Compreenda-se que um juiz que adote a teoria de que o cheque não é título de crédito, seria levado a declidir que, na falta de disposição, a prescrição seria de dez anos, aplicando o art. 203.

\section{5 - A exclusão da ação de enriquecimento indevido ("in rem} verso") (art. 204, § $3 .^{\circ}$ ). O Direito brasileiro tem admitido que, embora prescrito o título de crédito, subsiste a obrigação de pagamento, pela relação fundamental que Ihe deu origem. Assim, por exemplo, a letra de câmbio prescrita enseja a ação in rem verso, a fim de se impedir, em desproveito do credor, o enriquecimento indevido do devedor. Prescrevendo o título em três (art. 204, § $3^{\circ}{ }^{\circ}$ ) anos, subsiste o direito à cobrança da relação fundamental por vinte anos.

O Projeto concede aos títulos de crédito o prazo prescricional de três anos, e por igual, no mesmo art. 204, § $3 .^{\circ}$, inciso IV, em três anos, a prescrição da "pretensão de ressarcimento de enriquecimento sem causa".

Em consequência, a prevalecer o preceito indicado, excluido está a pretensão de credor por título de crédito prescrito de haver o ressarcimento da obrigação pela ação de enriquecimento sem causa.

Seria conveniente, em benefício do crédito coletivo, que o prazo da prescrição da pretensão fosse de cinco anos, deslocando-se o preceito para $\circ \S 5 .^{\circ}$, do mesmo artigo.

7.6 - limire de valor na prova testemunhal (ars. 225). O art. 225 reza que "salvo os casos expressos, a prova exclusivamente testemunhavel só se admite nos negócios jurídicos cuịo valor não ultrapasse o décuplo do maior salário mínimo vigente no País ao tempo em que foram celebrados".

Desde que o Governo proibiu a correção e atualização de valores monetários em função do salário mínimo, deve-se encontrar outro parâmetro para ajustar o valor do negócio jurídico suscetivel de prova por depo:mento testemunhavel. Assim, o preceito deve dar um valor monetário, corrigido em função dos índices fornecidos periodicamente pelo governo.

Sugerimos, assim, que o limite seja de o mínimo de $\mathrm{Cr} \$ \ldots$. $50.000,00$ (cinquenta mil cruzeiros) reajustáveis conforme os índices de correção monetária, fornecidos periodicamente pela autoridade competente. 
7.7 - O problema da correção monefária (art. 314) - Não nos parece satisfatória a solução apresentada pelo Projeto quanto ao envilecimento da moeda, consequência da inflação, quanto ao pagamento das obrigações em dinheiro.

Notemos que o art. 314 dispõe:

"São nulas as cláusulas de revalorização da moeda, excetuados os casos previstos em lei, ou quando se tratar de dívida de valor.

Parágrafo único. É lícito, porém, convencionar o aumento progressivc de prestações sucessivas".

$\mathrm{O}$ art. 316 completa:

"Quando, pela desvalorização da moeda ocorrer desproporção manifesta entre o valor da prestação devida e o do momento da execução, poderá o juiz corrigi-lo, a pedido da parte, de modo que preserve, quanto possível, a equivalência das prestações".

Como se vê, o Projeto admitiu a existência do problema do envilecimento monetário, mas não teve a coragem de aplicar-lhe, como corretivo a ałualização monetária, conforme os índices oficiais. Manter-se-ia, assim, o privilégio apenas da Fazenda Nacional e das instituição financeiras, aquinhoadas pela Lei com a correção monetária. Todos os outros casos ficariam dependentes de incômodo critério do juiz.

A desvalorização da moeda tem sido, com razão, apontada como uma vantagem do devedor, que posterga o pagamento de seus débitos para se aproveitar da desvalorização da moeda, que funciona em seu favor. O Supremo Tribunal Federal, no relatório apresentado ao Sr. Presidente da República, pôs em relevo a circunstância de que a desvalorização da da moeda tem sido, com efeito, usada como uma técnica protelatória do devedor, aumentando expressivamente, em consequência, o ingresso de causas injustas, assoberbando - Poder Judiciário. Por isso, propõe que a regra da correção monetário seja extensiva a todas as espécies de dívidas.

"9 - A pletora de processos civeis, entre mais razões que a explicarão, encontra estímulo no desgaste do poder aquisitivo da moeda e na inexistência de atualização ou correção monetária das condenações. Obrigado, pelo Estado, a recorrer-Ihe a jurisdição, para reparação incompleta e desvailosa, pela indispensável demora da demanda, com benefício do litigante sem razão. Essa 
evidente falha na aplicação da Justiça cumpre ser prontamente eliminada".

Por todos esses motivos, e sobretudo pelo princípio de equidade, a correção monetária deve ser declarada no Projeto como norma legal do efeito geral. Esta é, sem dúvida, no Projeto, a oportunidade de atender aos reclamos do Supremo Tribunal Federal.

7.8 - Contagem de juros (art. 403). O art. 403, do Projeto, estabelece a regra:

\section{cial". \\ "Contam-se os juros de mora desde a citação ini-}

Sustentamos que o Código deve propugnar pela uniformidade de tratamento, e dos efeitos, de todos os institutos jurídicos que acolhe. Esse critério já aplicamos anteriormente nestas nossas observações, a respeito de discrepâncias de seu texto em relação a preceitos e normas de leis especiais.

Nos títulos de crédito, mais especificamente no Direito cambiário, vige regra contrária, a do art. 403, desde que a Lei Uniforme de Genebra estabelece no inciso $2 .^{\circ}$, do art. 48, que "o portador pode reclamar daquele contra quem exerce o seu direito de ação os juros à taxa de $6 \%$ (seis por cento) desde a data do vencimento".

Não há nenhuma razão de ordem lógica que determine tratamento diferente para a cobrança de juros de mora, por não ser obrigação cambiária. Desde que a obrigação seja a termo, e certa, não há razão para que não se mande contar os juros de mora desde o vencimeni̊o, da obrigação não cumprida.

7.9 - Omissão da "tradição simbólica" O Projeto, no Capítulo I, do Título VI, do Livro II, peca pela inspiração acentuadamente civilista com que projetou as normas do contrato de compra e venda. E necessário que se reconheça a evidência que a compra e venda é um contrato básico do comércio, em cujo âmbito se realiza em massa. Não encontramos, com efeito, em seu texto, regras relativas à tradição simbólica, importantíssima nos contratos mercantis feitos entre praças diversas.

O art. 480 mantém o princípio de que a compra e venda constitui um contrato de natureza pessoal e não real, como é de nossa tradição jurídica. Assim sendo, o contrato não importa, desde logo e por si, na transferência da coisa. O vendedor assume a obrigação da transferência. O contrato se cumpre, portanto, com a tradição da coisa. 
Com efeito, assim dispõe o art. 480:

"Pelo contrato de compra e venda, um dos contratantes se obriga a transferir o domínio de certa coisa, e - outro, a pagar-ihe certo preço em dinheiro".

Em face da teoria dominante no Projeto, assume de fato a tradição um efeito de excepcional importância. Imprescindível, sobretudo para as relações comerciais em massa, que se regule a entrega ou tradição simbólica, atualmente disciplinada no art. 200 do Código Comercial:

"Art. 200. Reputa-se mercantilmente tradição simbólica, salvo a prova em contrário, no caso do erro, fraude ou dolo:

$10^{\circ}$ - A entrega das chaves do armazem, loja, ou caixa em que se achar a mercadoria ou objeto vendido;

$2 .^{\circ}$ - O fato de por o comprador a sua marca nas mercadorias compradas, em presença do vendedor ou com o seu consentimento;

$3 .^{\circ}$ - A remessa e aceitação da fatura, sem oposição imediata do comprador;

$4 .^{\circ}$ - A cláusula - por conta - lançada no conhecimento ou cautela de remessa, não sendo reclamada pelo comprador dentro de três dias úteis, achando-se o vendedor no lugar onde se receber a cautela ou conhecimento, ou pelo segundo correio ou navio que levar correspondência para o lugar onde ele se achar;

$5^{\circ}$ - A declaração ou averbação em livros ou despachos das estações públicas, a favor do comprador, de acordo de ambas as partes".

Por igual seria conveniente, a fim de espanar todas as dúvidas doutrinárias, que o Código disciplinasse os efeitos das cláusulas CIF e FOB, que adjetivam certos contratos de compra e venda feitos entre praças diversas.

Como se vê, o capítulo da compra a venda, no Projeto, elaborado por um insigne civilista, se ressente de um toque mercantil, pois nesse campo e nessa técnica há uma diferenciação notável da compra e venda civil. Esta é feita em atos isolados, aquela é feita geralmente em massa, constituindo o núcleo, em geral, de toda a atividade mercantil. 


\subsection{0 - Rescisão antecipada dos contratos de locação a tempo}

determinado (art. 568). O Projeto repetiu, no art. 568, a regra do atual art. 1.193 § único, do Código vigente:

"Havendo prazo estipulado à duração do contrato, antes do vencimento não poderá o locador reaver a coisa alugada, senão ressarcindo ao locatário as perdas e danos resultantes, nem o locatário devolve-la ao locador, senão pagando o aluguel pelo tempo que faltar".

Destacamos do texto a obrigação penal do locatário que devolve ao locador a coisa, antes do término do prazo contratual. A pena é pagar-lhe o aluguel pelo tempo que faltar. Sem dúvida essa sanção é extremamente severa e draconiana. O locador que viu, desmotivadamente, o contrato rescindido, terá sem dúvida direito a um ressarcimento, mas o fato é que adquire novamente a disposição da coisa para locá-la a preço atual. Pelo preceito, tem ele uma dupla vantagem, uma dupla renda, sobre a mesma coisa.

A jurisprudência de nossos tribunais recrimina o draconismo da regra do art. 1.193, § único. Disso constitui modelo a sentença do juiz Washington de Barros Monteiro, hoje um dos mais insignes civilistas, professor que é da Faculdade de Direito de São Paulo:

"Esse dispositivo, como acentua o réu, no seu memorial de fls., tem merecido justas críticas dos nossos comentadores, pois coloca o locador em situação de manifesta vantagem. sobre o locatário. No caso sub judice essa posição mais favorável do locador ficou nitidamente realçada com a circunstância de ter ele arrendado novamente as terras a terceiro, depois de recebe-las do antigo locatário. O locador virá assim a receber dois alugueres sobre a mesma coisa, relativos ao mesmo período de tempo.

Todavia, como brilhantemente acentuou o Ministro Bento de Faria, em acórdão proferido no S.T.F., o juiz não é censor da lei, nem lhe pode ser atribuida a função de legislador (Vide Arq. Jud., 58/238).

Ao Judiciário, não cabe discutir a conveniência do preceito legal, senão cumpri-lo, quer em sua letra, quer em seu espírito (acórdão do T. de A. do Estado, D. Of., de 7-12-1.940, processo 9.538). A regra do art. 1.193, parágrafo único, não pode deixar de ser aplicada, por maiores que sejam as reservas que mentalmente possa- 
mos opor ao seu conteúdo" (Confirmada pela 2. ' Câmara do T.A. de São Paulo, in R. Tribs. 140/605).

Clovis Bevilaqua comentando essa regra, afirma que "parece que a intenção do legislação foi estabelecer igualdade entre as partes, mas o efeito alcançado foi outro" (Cod. Civ. Com. vol. II D. 376).

Como os Srs. Deputados hão de estar lembrados em outubro do ano passado o Sr. Presidente da República encaminhou Mensagem ao Congresso Nacional, propondo uma consolidação geral das leis relativas à locação de prédios urbanos. Projeto elaborado que foi pelo Ministério da Justiça, da Fazenda e do Planejametno. Esse Projeto dispunha no art. 26, parágrafo único, que:

"Não se aplica às locações reguladas nesta lei o disposto no parágrafo único do art. 1.193, no art. 1.196, no parágrafo único do art. 1.197, e no art. 1.209 do Código Civil"

Infelizmente o Projeto não teve seguimento, pois nos parece que posteriormente foi retirado.

O fato importante, a considerar, é que a revogação desse preceito do vigente Código Civil foi objeto de intenção do governo, merecendo, porisso, nesta oportunidade de revisão, ser corrigido. O preceito, deve ser amenizado, tendo em vista as justas críticas da doutrina e da jurisprudência que sobre ele pesam.

Estipule-se, pois, o direito do locador à perdas e danos, ou uma indenização prevista em cinqüenta por cento dos aulgueres vincendos. E mais equitativo.

7.11 - Gratificação ao depositário (art. 636). O art. 636, nos contratos de depósito voluntário, no parágrafo único, dispõe:

"Este contrato é gratuito, mas as partes podem estipular que o depositário seja gratificado".

Não podemos desconhecer que o depósito voluntário constitui, no comércio, um negócio altamente difundido e utilizado. A gratuidade, nesse caso, não é regra, mas sim exceção. Em qualquer caso, porém, em que as partes estipularem a onerosidade do contrato, não enseja ele uma grafificação, como diz o texto, mas uma remuneração. Gratificação, na linguagem jurídica, tem um sentido de liberaiidade, que não é o caso do preceito indicado. Deve-se, pois, falar em remuneração e não em gratificação. 
Aliás, confrontando-se o art. 636 com o seguinte, art. 637, notase desde logo a impropriedade técnica da apresentação das regras fundamentais do contrato de depósito. A afirmativa de que o contrato é grałuito é logo desmentida no artigo seguinte, parágrafo único, que admite ser ele oneroso...

O melhor seria abandonar essa qualificação regulando apenas o contrato, sem alusão à sua gratuidade, pois, como já demonstramos, ele serve intensamente ao comércio, podendo constituir base de atividade empresarial.

7.12 - Contrato de agência ou distribuição, (art. 727). $O$ contrato de agência nada mais é do que o atual contrato de representação comercial, objeto da legislação especial, contida na Lei n. ${ }^{\circ}$ 4.886, de 9 de dezembro de 1.965. Constitui importante contrato no moderno mundo comercial, e é exercido por centenas de milhares de profissionais, distribuidos por todas as praças do país. A denominação do instituto foi tirada do Código italiano, que o regula, mas estamos certos de que a linguagem do Projeto não deslocará o uso correntio da expressão "representação comercial", que podia ser perfeitamente mantida. Embora o Projeto faça tabú da expressão "comercial", não pode evitar o seu uso nos artigos 19 e 20, quando se refere a "propaganda comercial" ou a "fins comerciais". . Não seria criticável se mantivesse a denominação "representação comercial", já consagrada nos costumes da País, e em nosso Direito.

O art. 727 merece, entretanto, outros reparos. Dispõe esse preceito:

"Se a dispensa se der sem culpa do agente, terá ele direito à remuneração até então devida, e de conformidade com a lei especial, à relativa aos negócios pendentes, mais perdas e danos".

Muito embora, em "Exposição de Motivos", o Prof. Miguel Reale, tenha feito menção que o Projeto incluiu na sistemática do Código a matéria contida em leis especiais promulgadas após 1916, alterou profundamente, aquí, os direitos relativos ao agente comercial, ao conceder-lhe indenização de perdas e danos ao invés de indenização tarifada de que fala a Lei especial referida. Na verdade a Lei . $^{\circ} 4.886$, de 1965, estabelece que sendo a ruptura do contrato feita pelo comitente, o representante tem direito, sendo o contrato escrito, a uma indenização de $1 / 20$ avos das comissões até então auferidas, e se for não escrito de 1/15 avos.

Evita-se, assim, com a norma da lei especial, as demandas e 
dificuldades na fixação das perdas e danos, desviando do Judiciário um sem número de pendências.

O preceito do Projeto deve ressalvar a indenização tarifada, regulada em Lei especial.

Temos conhecimento de representação feita a esta douta Comissão pelas entidades de classe dos representantes comerciais a respeito desse assunto, bem como sobre a antinomia entre os arts. 720 e 723 do Projeto, reguladores da exclusividade.

O contrato de agência comporta, como é técnica do comércio, a exclusividade, tanto concedida pela representada como pelo agente. E a exclusividade ativa e a exclusividade passiva. Essa exclusividade deve ser a regra, e a não exclusividade a excepção. Esse critério é louvavemlente seguido pelo Projeto, mas o art. 723, pela redação que foi adotada, merece ser melhor ajustado àquela regra do art. 720 .

7.13 - O privilégio do crédiło do agente e do distribuidor: Ainda dentro das regras de simetria e uniformidade dos princípios que determinam as normas adotadas no Projeto, arguimos o problema da diferenciação de tratamento entre os créditos do comissário e o do agente e distribuidor.

Tanto o comissário (art. 702), como o representante ou agente e distribuidor (art. 719), atuam intensamente no mercado, como intermediários do comércio. São agentes auxiliares, sem dúvida.

Em nosso livro de comentários à Lei 4.886, de 1965, intitulado "Do Representante Comercial" (edição Editora Forense S.A.), tivemos oportunidade de esclarecer qu a intermediação, no comércio do Brasil antigo, era feito, entre diferentes praças, por meio da comissão mercantil. A introdução da represetnação comercial veio simplificar essa atividade, substituindo os contratos de comissão mercantil pelos contratos de representação comercial. Tecnicamente esses contratos, como o do mandato comercial, têm origem na locação de serviços.

Ora, nessas condições, parece-nos justo que os créditos dos representantes comerciais tenham o mesmo tratamento que os créditos dos comissários.

O art. 716 do Projeto estabelece:

"O crédito do comissário, relativo a comissões e despesas feitas, goza de privilégio geral, no caso de falência ou insolvência do comitente". 
Esse preceito merece ser repetido no que concerne aos contratos de agência e distribuição.

Ocorre-nos, ainda, na sustentação da tese acima defendida, de que há uma identidade entre a figura da comissão e do mandato, e a agência ou distribuição, está reconhecida no art. 730 do Projeto. Essa regra determina que "aplicam-se ao contrato de agência e distribuição, no que couber, as regras concernentes ao mandato e comissão e as constantes de lei especial". Assim, à primeira vista, seria despicienda a repetição do preceito de que a agência e distribuição gozariam em seus créditos do mesmo privilégio que gozam os créditos da comissão.

Temos a considerar, entretanto, que a matéria de privilégio é de interpretação estrita, não se podendo estende-la por analogia. Porisso impõe-se a inclusão, no Capítulo VII, consagrado à agência ou distribuição, de uma emenda aditiva, que assegure o privilégio. Poderia ser assim redigida:

"O crédito do agente ou do distribuidor, relativo a remuneração e despesas feitas, goza de privilégio geral, no caso de falência ou insolvência do comitente.

7.14 - 0 transporte e a coisa perecível. O art. 759 dispõe:

"Se o transporte não puder ser feito ou sofrer longa interrupção, o condutor solicitará, incontinente, instruções ao remetente, e zelará pela coisa, por cujo perecímento ou deterioração responderá, salvo força maior.

"Se o impedimento for de responsabilidade do transportador, este poderá depositar a coisa, por sua conta e risco, mas não poderá vende-la, se perecível".

Pergunta-se, então: se a coisa for não perecível, poderá o transportador vende-la? Faz necessário esclarecer, no texto, que tanto uma como outra qualidade da coisa impedem a venda pelo transportador culpado pelo retardo do transporte. Poderia, ao nosso ver, ser adotada, no final, do parágrafo segundo, a expressão: "mesmo que seja perecível".

Assim dar-se-á a certeza de que o transportador não pode vender a cousa, seja ou não seja ela perecível.

7.15 - Encerramento da conta de depósito bancário conjunta (art. 866, § $1^{\circ}$ ) Entre os contratos bancários, do Capítulo XXII, do Livro I, figura o de depósito bancário. Reza o art. 866: 
"Pelo contrato de depósito bancário, o banco recebe uma quantia em dinheiro, e se obriga a restituir ao depositante valor correspondente na mesma espécie.

$\S 10^{\circ}$ O depósito conjunto pode ser levantado, total ou parcialmente, por qualquer dos titulares da conta, salvo convenção diversa".

$\S 2 .^{\circ} \ldots$

As contas conjuntas foram introduzidas em nosso sistema bancário graças à parecer favorável dado por J.X. Carvalho de Mendonça, quando Consultor Jurídico do Banco do Brasil. Disse o mesmo comercialista:

"Não há inconveniente na formação de contas conjuntas ou coletivas, permitindo a cada um dos seus titulares emitir cheques ou ordens de pagamento à vista sobre o banqueiro, em favor próprio ou de terceiros, até a concorrência dos fundos disponíveis. Se os fundos são depositados por duas ou mais pessoas, ajustando expressamente a solidariedade ativa, cada uma, credor solidário, poderá emitir sobre o banco depositário cheques ou ordens de pagamento à vista". (Tratado, vol. VI. 1.a Parte, nota a pg. 246).

Disseminou-se, depois disso, a conta conjunta sobretudo de conjuges, casados sob o regime de comunhão de bens. É preciso, porém, que o preceito do Projeto esclareça que a conta é encerrada em caso de falecimento de um dos depositantes.

O que se tem visto, nas contas conjuntas, é que, falecendo um dos depositantes, o sobrevivente imediatamente saca a importâncıa depositada, com prejuízo para a herança.

Impõe-se, portanto, a regra de que o depósito bancário conjunto cessa com o falecimento de um dos depositantes, liquidando-se a conta respectiva entre os interessados.

\section{PARTE}

\section{A ATIVIDADE NEGOCIAL}

8.1 - A empresa. O projeto, sob a direta influência do Código Civil italiano, de 1942, não define empresa, mas apenas o empresário. 
Os legisladores italianos, reconhecendo que o Direito não havia ainda conseguido formular o conceito jurídico de empresa, contentaram-se em figurar o empresário como a pessoa que desempenha uma atividade econômica. Atividade essa organizada para produção ou a circulação de bens ou de serviços. Houve, assim, no art. 1.003, o transplante puro e simples do conceito de empresário do Código italiano para o Projeto.

A empresa seria, então, a atividade. A atividade econômica do empresário "para a produção ou a circulação de bens ou de serviços".

Pode parecer estranho que se adote como fulcro de um sistema legal um instituto ainda não bem delineado ou definido pela ciência jurídica. Mas assim tem sido, sobretudo no direito comercial, pois até hoje não se definiu o "ato de comércio", que continua como um conceito nebuloso. E no entanto foi ele a pedra angular de todo o sistema do Código napoleônico, de 1807, que inspirou o nosso atual Código Comercial.

Não diz o Projeto que a empresa, ou melhor, o empresário pode ser civil ou comercial. Para os seus autores a expressão "comercial" é tabú, diante da preocupação unificadora, como já tivemos oportunidade de registrar. O fato, porém, é que teremos na linguagem comum do mercado o "empresário comercial" e o "empresário

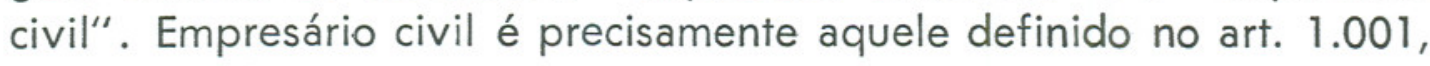
parágrafo único:

"Não se considera empresário quem exerce profissão intelectual, de natureza científica, literária ou artística, ainda com o concurso de auxiliares ou colaboradores, salvo se o exercício da profissão constituir elemento de empresa".

Podemos, desde já. prever as dificuldades em caso de profissão intelectual ou científica, com dezenas de funcionários, em não se the aplicar a noção de empresa. Ainda mais quando a legislação trabalhista assim expressamente a considera...

Toda a organização que contar com uma quantidade de colaboradores, deveria ser tratada como empresa. Nela haverá a organização do trabalho alheio. Difícil é conceber-se uma organização, mesmo intelectual ou científica, que pelo menos não se dedique à pesquisa, esta sempre de utilidade econômica.

Além do mais o Projeto, incoerentemente, reconhece a existência de o empresário rural, quando exclui da obrigação de se ins- 
crever no registro da empresa. Ora, isso não tem razão de ser, pois desde que, na indústria agrícola ou pastoril, se organizem capitalisticamente os fatores da produção, merece esse organismo o tratamento de empresa. Assim o Projeto deveria sem receios estender à atividade agrícola e pastoril, organizada, e com certo número de colaboradores, o conceito de empresa, sendo dispensável, como faculdade, contida no art. 1.008, de ser registrar no Registro das empresas, e a do art. 1.021 .

Aliás em pról dessa nossa sugestão, invocamos declaraçõse recentes do Ministro da Agricultura, que recomendava a organização da empresa rural, única organização capaz de atender aos reclamos técnicos e científicos da pordução agrícola e pastorial em nossos dias, facilitando sobremaneira a ação estimulante do governo.

O Capítulo !, Título I, Livro II, merece, pois, ser objeto de muita meditação, a fim de que o conceito de empresa dele surja bem nítido. Ademais, não devemos nos esquecer de que o direito falimentar não sofre os efeitos da unificação, se destinando exclusivamente às empresas comerciais.

8.2 - A atividade empresária do incapaz, (art. n. ${ }^{\circ} 1.011$ ). O Capítulo II, do Livro II, trata da capacidade para ser empresário. Admite que, por meio de representante ou devidamente assitido, poderá o incapaz continuar a empresa antes exercida por ele enquanto capaz, por seus pais ou pelo autor da herança.

O parágrafo primeiro dispõe que, em tais casos,

"precederá autorização judicial, após exame das circunstâncias e dos riscos da empresa, bem como da conveniência em continua-la. Essa autorização pode ser revogada pelo juiz, ouvidos os pais, tutores ou representes legais do menor ou do interdito, sem prejuízo dos direitos adquiridos por terceiros".

Esse problema tem sido debatido na doutrina pelos comercialistas, que, dada a complexidade da matéria, não se conciliam (Cfr. nosso "Curso de Direito Comercial", n. ${ }^{\circ} 52$ ).

Sustentamos, com o Prof. Eunápio Borges, catedrático da Universidade Federal de Minas Gerais, que o incapaz, sobretudo o interdito, seja por loucura ou prodigalidade, não pode ser comerciante. $\mathrm{Na}$ interdição superveniente, do comerciante, a solução é a mesma: proceder-se-á à liquidação do estabelecimento.

Assim também sustentamos que deva ser, e combatemos a so- 
lução encontrada pelo Projeto. Os riscos do comércio são muito graves, e difícil ao Juiz, que não é expert em assuntos econômicos, aquilatar, como previsão, os riscos a que a empresa está sujeita...

Aliás, no $\S 2 .^{\circ}$, o Projeto abre um grave precedente, de limitação de responsabilidade patrimonial do comerciante individual, tão discutida no Direito moderno. Diz o preceito:

"Não ficam sujeitos ao resultado da empresa os bens que o incapaz já possuia, ao tempo da sucessão ou da interdição, desde que estranhos ao acervo daquela, devendo tais atos constar do alvará que conceder a autorizazação".

O patrimônio afeto à empresa, que o incapaz herdar, constituirá, como se vê, um patrimônio separado, sobre o qual se resumirá a sua responsabilidade empresarial. Será difícil, a certa altura, discernir, fora do campo imobiliário, quais os valores que antes pertenciam ao incapaz, e quais os havidos com a empresa.

A maior cautela aconselha afastar, e não facilitar, o comércio dos incapazes, em proveito de sua segurança patrimônial.

8.3 - A atividade empresarial do menor (1.011, $\left.\S 3 .^{\circ}\right)$. Dispondo sobre o problema da minoridade em face a empresa, o $\S 3 .^{\circ}$ do art. 1.011, dispõe:

"Completando o menor a idade de dezoito anos, porá ser autorizado pelo juiz a assumir a direção da empresa, ouvindo o pai ou, na falta, a mãe, e, nos demais casos ,o representante legal. A autorização implica emancipação".

Veste o Projeto de roupagens novas o antigo instituto do Código Comercial da autorização do menor para comerciar. Dispõe o art. $1 .^{\circ}, \S 2 .^{\circ}$, desse Código, "os filhos famílias que tiverem mais de 18 anos de idade, com autorização dos pais, provada por escriitura pública" podem comerciar no Brasil.

Cabia, pois, aos pais, no exercício do pátrio poder, a faculdade de autorizar ou não ao filho menor com mais de 18 anos, a comerciar. E essa artibuição não é, no regime jurídico vigente, suprível pelo juiz, que não se pode sobrepor ao pátrio poder. Sempre sustentamos ademais que a autorização paterna não equivale ou não resulta em emancipação. Constitui o sistema da autorização uma forma de capacidade típica e especial criada pelo direito comercial.

O Projeto subverte, todavia, o atual sistema. Concede ao juiz 
a autoridade de autorizar o menor para assumir a direção da empresa, ouvido o pai ou, na falta, a mãe, e, nos demais casos, o representante legal.

No momento em que se propõe uma reforma do Poder Judiciário, a fim de dele desviar a carga de atribuições que pesa sobre o Juiz, não tem sentido o preceito que faz depender dele uma decisão que pode ser perfeitamente tomada pelo pai, ou, na sua falta, a mãe e, nos demais casos, pelo seu tutor.

Ainda mais ,se essa autorização do juiz, ouvido o pai, importa, quando concedida, em emancipação, porque não aplicar desde logo a emancipação do menor?

O poder de autorizar ao menor o exercício da atividade negocial deve caber aos responsáveis do menor, que o conhecerão melhor do que o Juiz... E como a autorização equivale à emancipação, deve-se excluir a figura da autorização, para aplicação desde logo da emancipação.

\section{4 - 0 obrigatório registro do empresário (art. 1.004).}

Projeto, desde seus estudos preliminares, pretende instituir a obrigatoriedade do registro do empresário, sistema que não corresponde à tradição de nosso Direito. O Art. 1.028, do Anteprojeto, estava assim redigido: "Sob as sanções legais, deve o empresário, antes de iniciar a sua atividade, inscrever-se no Registro das Empresas da respectiva sede".

Nas sugestões que então apresentamos à Comissão Revisora, advertíamos que nenhuma sanção existe em nossa legislação, nem - Anteprojeto a estabelecia, para o empresário que não se inscrevesse no Registro do Comércio. O texto foi alterado, excluindo-se a ameaça da sanção, constando agora do Projeto a seguintes redação".

"É obrigatória a inscrição do empresário no Registro das Empresas da respectiva sede, antes do início de sua atividade".

Como se vê, a obrigatoriedade foi mantida. Excluiu-se apenas a sanção. A emenda procedida nada significa, pois obrigatoriedade sem sanção pouco representa no mundo jurídico...

Ora, a obrigatoriedade do registro do comerciante, denominado empresário no Projeto, não venceu em nosso País, por ocasião da implantação do Código Comercial, nos idos de 1850. Naquela ocasião, segundo dispunha o art. $4 .^{\circ}$ - "Ninguém é reputado comer- 
ciante para efeito de gozar da proteção que este Código liberaliza em favor do comerciante, sem que se tenha matriculado em algum dos Tribunais do Comércio do Império, e faça da mercancia profissão habitual" -, tornava-se requisito essencial para qualificação de comerciante a matrícula no registro do comércio. Como o Capítulo III concedia as "perrogativas dos comerciante", passou-se a conceber que a elas concorriam apenas os comerciantes matriculados, do que decorreria a classificação de "comerciantes legais" e "comerciantes de fato". Assim, não aplicar-se-ia o Código aos comerciantes não matriculados... Essa esdrúxula interpretação foi logo desautorizada pelo Conselho de Estado do Império, que foi levado a reconhecer que as regras do Código se aplicavam a todos os comerciantes matriculados ou não. Vingava o princípio de que a matrícula não era obrigatória.

Num país em desenvolvimento, com grandes extensões ainda subdesenvolvidas, marcadas pela ignorância e analfabetismo, será uma temeridade do Projeto exigir que todo o empresário comercial venha a inscrever sua empresa no Registro próprio.

Não estabelecendo sanções legais específicas, nas quais incorrerá a empresa que não for registrada, poder-se-á aplicar à omissão a Lei de Contravenções Penais, pois o empresário sem empresa registrada exerceria sua atividade negocial sem habilitação, que decorreria do registro. A falta do registro configuraria o exercício ilegal da profissão.

O simples bom senso está a indicar à impossibilidade de se se punir, criminalmente, todas as empresas pequenas e médias que existem, pelo Brasil afora, sem inscrição no atual Registro do Comércio, que passaria a se denominar Registro de Empresas, consoante 0 art. 1.184 do Projeto.

A experiência e a observação do meio brasileiro, sobretudo do interior, leva-nos à conviç̧ão de que o Registro obrigatório das empresas será uma vã tentativa: acabará em desuso como norma coercitiva pela impossibilidade de punição criminal das empresas sem registro.

Melhor seria conservar o sistema atual da facultatividade, mas cercar a falta do registro de tais e funestas consequências que o empresário, por interesse próprio, naturalmente seria levado ao registro. Sabe-se que atualmente o registro é facultativo, mas, se não for efetuado, o comerciante não terá seus ilvros comerciais legalizados e, consequentemente, sofre gravosa tributação do imposto de ren- 
da e, em caso de falência, esta será fraudulenta e, por igual, não terá direito à concordata preventiva.

Sugerimos, pois, que o futuro Código espose a realidade brasileira, excluindo a obrigatoriedade do Registro da empresa, para filia-lo ao sistema atual da facultatividade. O preceito seria, pura e simplesmente, eliminado.

8.5 - Sociedade simples (arts. 1.035 a 1.075). O Projeto dedica um Capítulo inteiro à sociedade simples, a exemplo do que fizera o Projeto de Código de Obrigações de 1965. Desde então temos combatido a introdução dessa nomenclatura em nosso Direito, pois representa ela nada mais do que a sociedade civil, servindo como base, como substractum aos vários tipos de sociedades comerciais a que o Projeto chama de sociedade empresária.

Não nos parece esse o melhor sistema, subvertendo totalmente a tradição do direito brasileiro, que muito bem atendeu, até hoje, às necessidades jurídicas e técnicas no campo das sociedades. Pelo sistema adotado a todo o instante a doutrina e a jurisprudência seriam chamadas a opinar e decidir sôbre quais os princípios das sociedades simples que the são específicos e quais os gerais, para serem aplicados aos outros tipos de sociedade.

Seria mais conveniente que fosse mantido o regime atual e adotado pela maioria das codificações, estabelecendo-se os princípios gerais que presidem as sociedades. Hoje, a doutrina pátria já admite e concorda em ver, no contrato plurilateral, o tipo de contrato que se ajusta à constituição da sociedade comercial e civil. Partindo, portanto, da noção de contrato plurilateral, seria fácil ao Projeto estruturar mais amplamente o capítulo dedicado às disposições gerais a que estão sujeitas todas as sociedades. $E$, em seguida, nas disposições especiais, os preceitos peculiares a cada tipo. Como está estruturado o Projeto, amiudam-se as remissões a outros artigos, desorientando ou afadigando a exegese. Tome-se, por exemplo, o art. 1.077: "A sociedade em nome coletivo se rege pelas normas deste captítulo e, no que seja omisso, pelas do capítulo precedente". O art. 1.083: "Aplicam-se à sociedade em comandita simples as normas da sociedade em nome coletivo, no que sejam compatíveis com as deste capítulo". Art. 1.090: "A sociedade limitada rege-se, nas omissões deste capítulo, pelas normas da sociedade simples". E muitos outros.

Não nos parece, repetimos, esse o melhor método de legislar, muito embora essa colocação da matéria tenha sido transposta do Código italiano. Mais lógico e racional, é o sistema adotado tradi- 
cionalmente pelo nosso direito, com um desenvolvido capítulo destinado a regular, largamente, os fundamentos básicos e comuns de todas as sociedades, especialmente as personalistas.

A sociedade simples não tem história, ressalta o professor Brunetti, em seu "Trattado del Diritto dele Societá". "La societá sem plice non ha una propria storia perchè é nata col codice del 1942".

E estudando o conceito geral da sociedade simples o professor de Veneza explica porque o Código unificado de 1.042 teve que se valer da figura usada pelo Código de Obrigações suíço, para transpo-la para o direito italiano.

Explica Brunetti o regime da sociedade civil, no antigo Código, de inspiração romanista, na qual os sócios eram singularmente proprietários dos bens, credores da atividade, devedores das obrigações sociais. Nas relações com terceiros se obrigavam pessoalmente. A responsabilidade que delas derivava era independente do domínio da sociedade, que permanecia numa situação interna ignorada do público. Não só era assente a idéia de um diverso sujeito mas os sócios permaneciam individualmente titulares dos bens destinados ao exercício social. O conceito de patrimônio que se projeta nas relações para com os terceiros é, por isso, estranho à sociedade civil do velho tipo. O contrato, prescindindo do pressuposto da comunhão, criava somente obrigações entre os sócios, donde qualquer ato deles incidia sobre o próprio patrimônio singular. Por tal origem histórica a sociedade civil configurava-se como união contratual de muitas pessoas; não como entidade jurídica e nem mesmo como núcleo patrimonial.

Não se revestia a sociedade civil de personalidade jurídica, nem nela existia a noção de autonomia patrimonial, como se vê.

Daí, porque a "Relazione", que apresentou o Código italiano, registrou com precisão e clareza: "Appunto nel riconoscimento dell'autonomia patrimoniale si pone differenza sostanziale brail regolamento delle società semplice e quella della società civile, secondo il codice del 1.965: cosí si spiega l'accoglimento nell" art. 2.256 di um princípio diverso da quelo dall'art. 1.723, nn. 2 e 3, cosí sí spiega l'adoziene di nome como quelle degli art. 2267, 2268, 2270 e 2271, al cui applizione é, nei codici del 1865 e del 1882, limitatta alle società di commercio".

Não é demais que nos apoiemos também na dissertação do professor Osmida Innocenti sobre a sociedade simples, com que abre sua festejada monografia "A Exclusão de Sócio": "Não parece que a sociedade simples corresponda à velha sociedade civil - como 
pretende Putzolo - ainda que se encontre neste seu precedente imediato. E isso pela importante e decisiva consideração de que na sociedade civil regulada pelo Código Civil de 1864 faltava por completo a autonomia patrimonial, de modo que os sócios resultavam uti singuli proprietários dos bens, titulares dos créditos, devedores das obrigações sociais, sendo só a sociedade, como relação, uma mera situação interna, mais ou menos notória para os terceiros e inclusive completamente desconhceida pelos mesmos, enquanto abaixo do perfil contratual constituia fonte de obrigações somente para os sócios inter se, os quais no desenvolvimento da administração subordinavam-se segundo as normas próprias do mandato". Agora, não obstante a limitada autonomia patrimonial, afirmada em várias normas reguladoras da sociedade simples, vem a constituir a mais importante novidade da mesma frente a velha sociedade civil"...

A sociedade simples não tem firma, nem nome, no sistema italiano.

Não é preciso mais. A sociedade simples, no moderno direito italiano, possui um patrimônio autônomo em relação aos dos sócios, dentro do qual os credores sociais podem fazer efetivos seus créditos com prelação aos dos credores particulares dos sócios.

Justifica-se, dessa forma, ao legislador italiano reformular o veIho conceito romanista, imanente nas sociedades civis, da comunhão.

Tal necessidade não ocorre no direito brasileiro. A personalidade jurídica outorgada às sociedades em geral - comerciais ou civis - desde que tenham inscrito no registro próprio seus atos constitutivos, significa uma conquista da ciência jurídica a que não chegou até hoje, mesmo após a reforma de 1942, o direito privado italiano.

Tendo personalidade jurídica a sociedade civil tem patrimônio próprio. A autonomia patrimonial é a mais integral possível, e o sujeito desse direito precisamente é a sociedade civil. Não há, portanto, necessidade de se introduzir no direito que vai surgir um tipo novo de sociedade.

A sociedade civil é denominada agora pelo Projeto de sociedade simples. Entre nós, teria exatíssima procedência a afirmativa de Putzolo de que a "sociedade simples corresponde à velha sociedade civil".

A sociedade civil, como tipo de sociedade, deveria desaparecer com a unificação, passando a sociedade com objeto civil - rural, por exemplo - a tomar o tipo previsto de sociedade em nome coletivo, comandita simples, por quotas limitadas ou anônimas. 
A sociedade simples, como a velha sociedade civil, terá personalidade jurídica e, consequentemente, total autonomia patrimonial. Terá denominação. A responsabilidade dos sócios pelas obrigações sociais, que constitui outro ponto saliente da doutrina italiana, continua intacta no Projeto, em relação ao Código Civil vigente, mas de forma a confundir a sociedade simples com a de "nome coletivo", sobretudo quando nela for prevista cláusula de solidariedade.

Se não vejamos: $O$ Código Civil, art. 1.396, regula a responsabilidade dos sócios:

"Se o capital social não cobrir as dívidas da sociedade, por elas responderão os associados, na proporção em que houver de participar nas perdas sociais. Parágrafo único. Se um dos sócios for insolvente, sua parte na dívida será na mesma razão distribuída entre os outros".

Projeto, no art. 1.020, assim se apresenta, sem o complemento do parágrafo único, o que é lamentável omissão:

"Se os bens da sociedade não lhe cobrirem as dívidas, respondem os sócios pelo saldo, na proporção em que participam das perdas sociais, salvo cláusula de responsabilidade solidária".

Em síntese, não há nenhuma razão de ordem científica, nem técnica, nem prática, para se transladar para o direito brasieliro, ou novo tipo, ou nova nomenclatura de sociedade civil. Ao contrário do direito italiano e suíço o direito brasileiro já tem modernamente muito bem constituída a sua própria teoria das sociedades.

8.6 - A denominação da sociedade simples. (1.034, II). A sociedade simples não tem firma, nem razão social. Esta existe tão somente nas sociedades, ditas pelo Projeto, de sociedades empresárias. Mas o art. 1.034, ao enumerar as menções que o contrato de constituição da sociedade simples deve conter, no inciso II, indica a "denominação".

Assim, a sociedade simples terá uma denominação. Faltou, entretanto, ao Projeto indicar o modo de formação e configuração da denominação desse tipo de sociedade. Conterá ela o nome dos socios? Comportará denominação de fantasia? O que a caracterizará: a indicação "sociedade simples", por extensão ou abreviadamente $\mathrm{S} / \mathrm{S}$ ?

Ora, sendo a sociedade simples uma sociedade personificada, adquirindo em seu ato constitutivo por contrato escrito, essa perso- 
nalidade, é necessário que tenha, legalmente, uma denominação, que, com o nome, a assinale e identifique no meio econômico e social.

Ao regular, no Capítulo II, do Título IV o nome da empresa, o Projeto aludiu a todas as modalidades de nome (razão social ou firma, e denominação), esquecendo-se, entretanto, da sociedade simples.

Sugerimos, portanto, que a sociedade simples tenha sua denominação constituida da mesma forma que o nome das sociedades em nome de um ou de todos os sócios, ou de expressão de fantasia, seguida da palavra "sociedade simples" ou abreviadamente $\mathrm{S} / \mathrm{S}^{\prime}$.

8.7 - Sociedade Limiłada. (arts. 1.089 e segts). Já sustentamos, nas preliminares deste trabalho, nossa firme opinião de que as sociedades devem ser tiradas, como ocorre com as sociedades anônimas, do Projeto, para formarem, num todo sistematizado, uma lei geral das sociedades. Nossa opinião, portanto, sobre as sociedades, ditas empresárias, pelo Projeto, é apresentada com a ressalva de quem não concorda com o tratamento sistemático das atuais sociedades comerciais no Projeto.

Malgrado essa objeção básia, não podemos deixacr da aplaudir a intenção do Prof. Miguel Reale e dos seus companheiros de Comissão, quando afirma na "Exposição de Motivos" que o Projeto apresenta:

"d) minucioso tratamento dispensado à sociedade limitada, destinada a desempenhar função cada vez mais relevante no setor empresarial, sobretudo em virtude das transformações por que vem passando as sociedades anônimas, a ponto de requererem estas a edição de lei especial, por sua direta vinculação com a política financeira do País".

Com efeito, a sociedade limitada foi criada artificialmente pelos juristas do final do século passado, a fim de proporcionar mais uma opção à organização empresarial, em vista dos complexos formalismos das sociedades anônimas, que tendem a se agravar. As sociedades limitadas aligeiram e simplificam a estrutura jurídica da sociedade, de forma a se tornar a mais apta e ideal para a estrutura jurídica da pequena e média empresa.

No Brasil assistimos um fenômeno curioso, qual seja o de preferência, pelos empresários, das sociedades anônimas. Dois motivos básicos determinam a propensão dos empresários para optar pela es- 
trutura da sociedade anônima, para sua empresa. O primeiro foi revelado pela Comissão, quando apresentou o Anteprojeto de 1972, isto é, a vantagem fiscal oferecida pelas ações à taxação tributária dos dividendos. Com efeito, o sistema tributário, do Impôsto de Renda, protegia o contribuinte detentor de ações, com a facilidade de recolher, "na fonte", o imposto sobre a renda dos dividendos nas alíquota de $25 \%$, na sociedade anônima fechada, ou de $15 \%$ se se tratar de sociedade aberta. O segundo atrativo era, e é, a facilidade da transferência das ações, sejam ao portador, sejam meșmo nominativas.

O primeiro acicate desapareceu, desde que lei recente estendeu às quotas das limitadas o desconto na fonte do imposto sôbre os lucros a elas distribuidos. O segundo, isto é, as dificuldades de alteração do contrato social, quando da cessão de quotas, obrigando todos os quotistas a assinarem alteração do contrato social permanece, não dando o Projeto solução para essa dificuldade.

As sociedades limitadas tendem a se popularizar, como na Alemanha, onde existem apenas 3.000 sociedades anônimas, para dezenas de milhares de sociedades limitadas.

Porisso propomos que se reelabore o princípio da cessão e transferência das quotas, alijeirando nesse particular a funcionalidade dessas sociedades, relativamente à circulação de capitais.

Uma das críticas que se faz às sociedades por quotas, na sua configuração atual, é a forma arcaica e inconveniente de cessão e transferência das quotas. Qualquer retirada ou ingresso de sócio importa na modificação do contrato social, inconveniente que não requer maior análise.

Ora, o processo de cessão e transferência de quotas pode ser simplificado, ou com nova técnica, que assegurando os interesses da sociedade e dos credores, permita mais fácil acesso ou retirada do quadro social.

Aventou-se a idéia de que a sociedade fosse legalmente dotada de um livro de "Registro de Quotas" onde as cessões ou transferências seriam averbadas. A sociedade requereria, em consequência, obrigatoriamente ao registro do comércio o arquivamento de cópia autêntica do termo que valerá como instrumento de alteração contratual.

Em princípio é válida a idéia. A sociedade, pelo sistema indicado, poderia fiscalizar a regularidade da cessão e transferência caso no contrato houvesse cláusula de preferência dos antigos sócios 
na aquisição da quota do sócio retirante ou de necessaria anuência da admissibilidade do sócio que ingressa.

O que tememos, porém, é que a sociedade, por seu representante legal, não efetue a averbação no Regsitro do Comércio do termo de transferência ou cessão lavrado no livro de registro, por dissídio, ou má fé, prejudicando o sócio que se pretendeu retirar-se da sociedade.

Para afastar esse inconveniente poder-se-ia estabelecer que o contrato de cessão de quotas fosse levado à inscrição no Registro do Comércio, após o que, somente então, se faria a sua averbação no livro competente da sociedade. A validade do contrato de cessão ou transferência da quota surgiria somente após a averbação do contrato no livro próprio da sociedade.

8.8 - A penhorabilidade das quotas sociais. O Projeto não dá tratamento especial às quotas, como bem do devedor, em face de suas dívidas para com terceiros. Aplicam-se, às sociedades por quotas, a regra da sociedade simples, isto é, a do art. 1.063:

"O credor particular de sócio pode, na insuficiência de outros bens do devedor, fazer recair a execução sobre o que a este couber nos lucros da sociedade, ou na parte que the tocar em liquidação.

Parágrafo único. Se a sociedade não estiver dissolvida, pode o credor requerer a liquidação da quota do devedor, cujo valor, apurado na forma do art. 1.068, será depositado em dinheiro, no juízo da execução, até três meses após aquela liquidação".

Esse preceito parece-nos extremamente complicado e insuficiente para a garantia dos credores e para a comodidade da sociedade. Não será fácil a liquidação da quota do sócio executado, e mesmo que $\circ$ fosse a medida importaria na descapitailzação da sociedade, mal que todos devemos evitar, em benefício da empresa.

Permita-se-nos o desenvolvimento de nosso pensamento a respeito de tão grave problema.

A sociedade limitada tradicionalmente em nosso Direito é classificada entre as sociedades de pessoas, mas não menos verdade é que êlas se colocam no limiar das sociedades de capital. Estão, na verdade, no "divisor de águas", tomando também aspecto, algumas vezes de sociedade de capital. 
Daí a necessidade de estudar e regular cuidadosamente a penhorabilidade das quotas.

Constituia regra processual, no antigo Código de Processo Civil de 1939, que as quotas das sociedades comerciais eram impenhoráveis. Assim, como efeito, dispunha aquele Código, a saber: "Não poderão absolutamente ser penhorados: XII - Os fundos sociais, pelas dívidas particulares dos sócios, não compreendendo a isenção os lucros líquidos verificados em balanço". O art. 943, do mesmo diploma revogado, decidia": Poderão ser penhorados, à fatla de outros bens: II - Os fundos líquidos que possuir o executado em sociedade comercial".

A noma processual de então refletia o preceito do art. 292 do Código Comercial, que ainda determina:

"O credor particular de um sócio só pode executar os fundos líquidos que o devedor possuir na companhia ou sociedade, não tendo este outros bens desembargados. ou se, depois de executado, os que tiver não forem suficientes para o pagamento".

O Código de Processo Civil atual silenciou a respeito, o que dará, por certo, acentuados problemas para a doutrina e para a jurisprudência, que devem ser evitados pelo Direito substantivo.

Aqueles preceitos decorriam do princípio consagrado no Direito brasileiro, de que as sociedades comerciais regularmente registradas adquirem personalidade jurídica. Impressionados, portanto, com a autonomia patrimonial decorrente dessa personificação, os juristas levaram o princípio às últimas consequências: a quota do capital subscrita e integralizada pelo sócio, não respondia pelas suas dívidas particulares.

A jurisprudência dos tribunais tem considerado impenhoravel a quota do sócio nas sociedades por quotas de responsabilidade limitada, tendo todavia o Supremo Tribunal Federal distinguido: se no contrato social houver cláusula permissiva da transferência da quota independente da prévia anuência dos demais, torna-se viável a penhora; caso contrário, se o ingresso de novo sócio depender de concordância, a quota é impenhorável.

Precisamente para evitar fraudes e abusos da personalidade jurídica é que foi formulada a disregard doctrine, a que nos referimos ao comentar o art. 48 do Projeto.

Mas, estudando o importante tema da impenhorabilidade e trans- 
feribilidade das quotas, o jurista português Raul Ventura, da Universidade de Lisboa, em sua monografia "Cessão de Quotas" comenta:

'-'Não poder conceber-se que uma pessoa coloque todo o seu patrimônio ao abrigo da execução dos credores, transformando todo ele (salvo exceções relevantes) em quotas da sociedade: não pode admitir-se que um pacto entre certas pessoas produza efeitos relativamente a estranhos, restringindo ou até eliminando direitos destes provenientes de atos com os quais aqueles nenhuma relação possuem".

No direito comparado, deparamo-nos com a doutrina alemã no sentido da ineficácia de cláusula de instransmissibilidade ou da cláusula de consentimento, quando se trata de transmissão forçada, doutrina também adotada pelos juristas austriacos.

No direito italiano, o art. 2.480, alinea $3 .^{a}$, do Código Civil, estabelece que se a quota é livremente transferível e se 0 credor, o devedor e a sociedade não se põem de acordo, sobre a venda da quota, esta pode realizar-se em leilão, mas a venda fica sem efeito se, nos dez dias seguintes à adjudicação, a sociedade apresentar outro adquirente que ofereça o mesmo preço.

O sistema preconizado no Projeto é pernicioso para o credor. Sujeita-se, além da ação principal e sua execução de sentença, se for - caso, a um outro processo - que é o da liquidação da quota do devedor na sociedade de que seja sócio. Diz o art. 1.063,- relativo à sociedade simples, que se aplica por remissão às sociedades limitadas:

"O credor particular de sócio pode, na insuficiência de outros bens do devedor, fazer recair a execução sobre o que a esta couber nos lucros da sociedade, ou na parte que the tocar em liquidação.

Parágrafo único. Se a sociedade não estiver dissolvida, pode o credor requerer a liquidação da quota do devedor, cujo valor, apurado na forma do art. 1.068, será depositado em dinheiro, no juizo da execução, até três meses após aquela liquidação".

Argumentamos com $\circ$ inconveniente dessa solução para o credor, envolvido em sucessivas demandas para haver o que é seu. Para a sociedade, para os demais sócios que nada têm a ver com as dívidas particulares de seu companheiro, o incoveniente é maior, pois 
liquidada a quota, a sociedade tem que realizar o pagamento em dinehiro, descapitalizando sobremaneira a empresa, e a levando à ruina. Imaginemos, por exemplo, uma sociedade limitada de cinqüenta milhões de cruzeiros, e que a quota do sócio devedor seja de dez milhões; apurado esse valor, a sociedade teria que deposita-lo em juízo, dentro de três meses. Poucas sociedades limitadas, no Brasil, suportariam essa sangria.

Em vista de todas essas considerações, sugerimos que se estabeleça o sistema da plena penhorabilidade das quotas, mesmo que - contrato social consagre sua intransmissibilidade ou submeta a sua cessão à anuência prévia dos demais sócios. Penhorada a quota, levada a leilão, a sociedade ou os sócios, devem ter o direito de preferência ao licitante que melhor lance oferecer, adjudicando, a quota, desde que usem desse direito dentro de cinco dias, com o depósito do valor da arrematação. Se tal direito não for exercitado, o arrematante pode ingressar na sociedade com o sócio detentor da quota arrematada.

Pensamos que esse sistema se coaduna com a doutrina da penetração da personalidade jurídica, a que nos referimos anteriormente neste trabalho, com fulcro no art. 48 do Projeto.

8.9 - 0 abuso dos poderes de gerência (art. 1052). Ao abordar o excesso de poderes por parte dos administradores, fenomeno que no Direito indica-se como "ultra vires", o Projeto estabelece as seguintes regras:

"No silêncio do contrato, os administradores podem praticar todos os atos pertinentes a gestão da sociedade. Não constituindo objeto social, a oneração ou a venda de bens imóveis depende do que decidir a maioria dos sócios.

Parágrafo único. O excesso por parte dos administradores somente pode ser oposto a terceiros, se ocorrer pelo menos uma das seguintes hipóteses:

a) - Se a ilmitação de poderes estiver inscrita ou averbada no registro próprio da sociedade.

b) - Provando-se que era conhecida do terceiro.

c) - Tratando-se de operação evidentemente estranha aos negócios da sociedade".

Ao se tratar do tema do excesso de poderes do administrador ressalta-se a questão de seus efeitos em relação a terceiro de boa 
fé. Tanto na doutrina como na jurisprudência, já se havia assentado o princípio de que as restrições contratuais aos poderes dos gerentes não eram oponíveis, pela sociedade, aos terceiros de boa fé.

Devemos, todavia, distinguir duas hipóteses, de excesso de poderes:

a) - quando se trata de excesso em função do objeto social;

b) - quando se trata de excesso que se comporta dentro do objeto social.

Na primeira hipótese, descarta-se a boa-fé, pois o terceiro tratando com a sociedade, cuja finalidade social geralmente consta do nome comercial, como nas sociedades limitadas ou nas sociedades anônimas, toma ele conhecimento de que o negócio que realiza se desvia do objeto normal para o qual foi constituida a sociedade. Quem vende carne para um moinho de cereais, sabe que o diretor deste está fazendo mau uso de seus poderes, a não ser que exiba os poderes eșpeciais de que esteja investido, para o negócio excepcional que vai realizar.

Na segunda hipótese, o negócio é compatível com o objeto social, mas o administrador excede os poderes restritos de que foi investido. Neste caso, alguns pensam que o terceiro deveria examinar previamente os atos constitutivos da sociedade, arquivados no Registro dás Empresas, para verificar se o gerente possue poderes para praticar tais atos.

Essa é a hipótese que aflige os doutrinadores e juízes, e onde se acentuou a controvérsia, a qual se encontra hoje amenizada pela jurisprudência iterativa do Supremo Tribunal Federal e que o Projeto desconheceu .

Decidiu, na verdade, a alta Corte que:

"A firma social não se obriga perante terceiros pelos compromissos tomados em negócios estranhos à sociedade". (R.F. n. ${ }^{\circ} 361$, Jurisp. STF. vol. I, pág. 217, R.E. n. ${ }^{\circ}$ 68.104, de 23-9-1969.

"Embora contrariando o contrato, eis que firmado por um só de seus diretores, é válido o aval dado a terceiro de boa-fé, em nome da sociedade anônima. Ainda que o desvio da finalidade da forma, ou a infração do seu contrato social resulte do ato de uma única pessoa dirigente da mesma, o abuso por ela cometido não 
exonera a sociedade da responsabilidade em face de terceiro de boa-fé.

Compete à empresa zelar e observar os atos praticados por seus sócios dirigentes, não the sendo lícito alegar ignorância de tais atos, em prejuízo de outros, terceiros (E.R.E. n. ${ }^{\circ}$ 69.028, STF., Rel. Min. Thompson Flores).

"O requerente é terceiro de boa-fé, e nada tem a ver com as relações do avalista e com os prejuízos que - sócio-gerente possa causar à sociedade, pela inobservância do contrato social. Sobre a proibição contratual de a requerida avalisar títulos, só resta aos prejudicados valer-se dos arts. 10 e 11 da lei n. ${ }^{\circ} 3.708$, responsabilizando-se o sócio que abusou da firma". (STF. Rel. Sr. Min. Luiz Galloti, RTF 2/296).

Com efeito, a jurisprudência da Alta Corte sufragou a doutrina dominante. O Prof. Soares de Faria, em sua laboriosa monografia "Do Abuso da Razão Social" termina por afirmar que "o nosso Código não reconhece, nas sociedades coletivas, e em relação a terceiros, a validade de cláusulas que limitem a ação do gerente, no âmbito dos negócios designados no contrato".

Por sua vez J.X. Carvalho de Mendonça, explica que o Código Comercial somente se referiu ao emprego da firma em negócio particular do sócio gerente ou terceiros; há, porém, os casos frequentes do uso da firma em atos que, embora compreendidos no objeto da sociedade, são proibidos ao sócio gerente por cláusula contratual". Acha o comercialista que, "nesses casos, tratando-se de transações que constituem o objeto da sociedade, a firma, empregada pelo só cio gerente obriga a sociedade e os sócios. Assim o é, porque entre terceiro de boa-fé, que não tem direito de fiscalizar ou intervir na sociedade, e os sócios, vítimas de sua própria imprudência ou negligência na escolha do gerente infiel, mais equitativo é que sofram - prejuízo os que para ele concorreram direta ou indiretamente". Comenta, por fim, que "a lei visa amparar a boa-fé dos terceiros que trałam com a sociedade. Tenha-se sempre em consideração esse alvo legal e todas as questões a esse respeito serão aplainadas".

Em tese de concurso, "Do Aval", o Prof. J. Eunápio Borges expos interessante doutrina, pela qual o contrato social não pode derrogar os princípios de capacidade que a lei reconhece ou atribui a uma pessoa natural ou jurídica: "E qualquer acordo em sentido contrário, mesmo constando do instrumento devidamente registrado ou 
arquivado em registros públicos, será inoperante em relação a terceiro". Essas convenções limitativas de capacidade são válidas apenas entre os elementos que se obrigarem, mas não são oponíveis a terceiros de boa-fé. "Em relação a terceiros, porém, explica aquele autor, não terão elas, em hipótese alguma, o efeito de tornar incapaz ou menos capaz qualquer daqueles contratantes, mesmo que tal contrato esteja arquivado na Junta Comercial ou Registro de Títulos e Documentos. Não deixará, por isso, de ser válida a letra de câmbio ou a nota promissória que ele houver assinado como sacador, como aceitante, como endossante ou como avalista".

No direito comparado a solução legislativa não tem sido, via de regra, diferente. A recente reforma das Sociedades Comerciais, na França, lei n. ${ }^{\circ}$ 66.537, de 1966, dispõe que nas relações entre os associados e na ausência de determinação de poderes pelos estatutos, o gerente pode praticar todos os atos de administração no interesse da sociedade, e o art. 14 determina que nas relações com terceiros os gerentes obrigam a sociedade pelos atos compatíveis com o objeto social, e que as cláusulas limitativas dos poderes dos gerentes são inoponíveis aos terceiros. Houve, nesse setor, radical modificação da legislação francesa, pois no direito anterior prevalecia o princípio da plena publicidade da cláusula, que a tornava válida em relação aos terceiros de boa-fé.

O Código de Obrigações suiço e o Código germânico negam, peremptoriamente, a validade das cláusulas restritivas aos poderes de gestão. O Código germânico dispõe expressamente, no art. 126, alínea segunda, que "a limitação da extensão do poder de representação não é oponível aos terceiros".

A nova lei das sociedades anônimas da Alemanha, editada em 1965, no art. 82, dispõe que "o poder de representação da Diretoria não pode ser restringido. Nas relações entre os membros da Diretoria e a Sociedade, os membros da Diretoria são obrigados a respeitar as restrições concernentes ao poder de gestão que tiverem sido incluídos no quadro de prescrições relativo às sociedades por ações pelos estatutos, pelo conselho fiscal, pela assembléia geral e pelos regulamentos adotados pela diretoria e pelo conselho fiscal".

E o Código suiço, no art. 537, estabelece que os poderes de gerência confiados a um dos associados pelo contrato de sociedade não podem ser revogados nem restringidos pelos outros sócios sem justos motivos.

O antigo Código Comercial italiano admitia a validade da cláu- 
sula limitativa. O Art. 2.298, do Código Civil, manteve essa tradição, dispondo que "o administrador que tiver a representação da sociedade pode realizar todos os atos que se incluem no objeto social, observadas as limitações que resultarem do documento constitutivo ou da procuração comercial". As limitações não são oponíveis a terceiros, se não forem inscritas nos Registros das Empresas, ou se não ficar provado que terceiros tenham conhecimento delas.

O Projeto, como se percebe, abandonou a construção doutrinária e jurisprudêncial, elaborada por nossos juristas e pelos tribunais, para se inspirar na lei italiana...

Em nosso "Curso de Direito Comercial", ao abordarmos o tema em face ao antigo Projeto de Código de Obrigações de 1965, cujo art. 1.152, foi mantido pelo Projeto, sustentamos que é exigir demais que no âmbito do comércio, onde as operações se realizam em massa, avessas ao formalismo, que, a tcdo instante, o terceiro que contrata com uma sociedade solicite desta a exibição do contrato social, para verificação dos poderes do gerente. A. doutrina que dá validade a tal cláusula é evidentemente contrária às tendencias e espírito do dirito comercial. Tem razão o Prof. Eunápio Borges ao comentar que "além de sumamente nocivo à rapidez com que devem realizar-se os negócios comerciais, é de fato impráticável exigir-se, em cada caso, que terceiros examinem, nas Juntas Comerciais, os contratos ou estatutos das sociedades com que tratam".

O preceito incriminado do Projeto Art. 1.052, além da crítica doutrinária que comporta, apresenta grave redundância.

Diz, com efeito, o parágrafo único, que o excesso por parte dos administradores somente pode ser oposto a terceiros, se ocorrer pelo menos uma das seguintes hipóteses:

I - Se a limitação de poderes estiver inscrita e averbada no registro próprio da Sociedade.

11 - Provando-se que era conhecida do terceiro.

III - Tratando-se de operação evidentemente estranha aos negócios da Sociedade.

Ora, se a limitação aos poderes do administrador constante do contrato social estiver inscrita ou averbada no Registro do Comércio não será lícito, para os efeitos dessa regra legal, a ninguém alegar sua ignorância. O registro público, como todos sabem, imprime ampla publicidade aos atos nele inscritos ou averbados.

Redundante, em consequência, é a alínea II, pois a prova do 
conhecimento por terceiros da limitação decorre do conhecimento presumido resultante da averbação ou inscrição no Registro das Empresas, sendo portanto dispensável outra qualquer prova. E se o contrato social não estiver arquivado, não ocorre a publicidade da regra limitativa, e a prova do conhecimento do terceiro por outros meios não pode suprir a falta do registro.

Em face do exposto, esperamos que o legislador se mantenha fiel à jurisprudência do Supremo Tribunal Federal, à lição predominante dos doutrinadores pátrios e a realidade das atividades comerciais em nosso País, que não devem estar sujeitas às delongas de comprovações, nem sempre fáceis, dos poderes gerenciais, devido ao distanciamento entre as diversas regiões nacionais.

A redação do preceito poderia ser a seguinte:

"Os administradores podem praticar todos os atos pertinentes à gestão social, dependendo, entretanto, de deliberação da maioria dos associados ou sócios a oneração de imóveis ou a sua alienação, quando esta não constitua objeto social.

Parágrafo único: Os administradores respondem perante a sociedade pelo excesso que praticarem, ou pelas operações estranhas ao objeto social, não sendo oponíveis a terceiros de boa-fé as limitações de seus poderes".

8.9 - Alteração do contrato social por unanimidade. (Art. . . 1.036). Um dos problemas de Direito mais torturantes nos escritórios de advocacia de empresas é o da divergência dos sócios em relação ao contrato social. Para simplificar a exposição desse agudo tema, valemo-nos de nossa dissertação no "Curso de Direito Comercial", verbete n. ${ }^{\circ} 223$, que assim consta:

"Princípio da Maioria e a Alłeração do Contrato Social. O art. 331 do Código Comercial, ao dispor que a maioria dos sócios não têm faculdade de entrar em operações diversas das convencionadas no contrato sem o consentimento unânime de todos os sócios, admitiu que nos demais casos todos os negócios sociais serão decididos pelo voto da maioria, computado pela forma prescrita no art. 486. E o artigo invocado estabelece, no direito marítimo, a regra de que nas parcerias ou sociedades de navios, o parecer da maioria no valor dos interesses prevalece contra o da minoria nos mesmos interesses, ainda que esta seja representada pelo maior número de sócios e aquela por um só. 
As decisões sociais, portanto, são tomadas conforme o princípio da maioria, a não ser para a alteração do objeto social, para o qual requer-se unanimidade. Havendo empate, decide a sorte, se os sócios não preferiram cometer a decisão a um terceiro.

Esses salutares princípios, altamente democráticos, foram ultimamente postergados por nova legislação, de méritos discutíveis. A matéria merece atento exame.

A lei n. ${ }^{\circ} 4.726$, de 13 de julho de 1965, que dispõe sobre - Registro do Comércio, proíbe, pelo art. 38, no inciso V, o registro de "contratos sociais a que faltar a assinatura de algum sócio, salvo no caso em que for contratualmente permitida deliberação de sócios que representem a maioria do capital social". O preceito, como se vê, impede que contrato social seja registrado quando faltar a assinatura de algum sócio, o que é perfeito, pois já vimos que o contrato requer consentimento de quem se obriga, constituindo a assinatura o sinal desse comprometimento. Mas, acresce a ressalva de que "pode ser arquivado no caso em que for contratualmente permitida deliberação de sócios que representem a maioria do capital social".

Essa ressalva é impossível, pois em hipótese alguma pode um contrato ter validade sem a assinatura de todos os que nele se obrigam. Mas o texto do Decreto n. ${ }^{\circ} 57.651$, de 19 de janeiro de 1966, que regulamentou aquela lei, tenta o remendo desastrado, inserindo a hipótese de alteração do contrato de que o texto da lei não cogitou. Assim, dispõe o inciso $V$ do art. 71 que não podem ser arquivados "os contratos sociais a que faltar a assinatura de algum sócio e nos casos de alìeração de contrato só será permitida essa falta, caso contratualmente permitida deliberação de sócios que representam a maioria do capital".

É claro que o Regulamento não pode alterar a lei, nem mesmo para corrigi-la. A autoridade administrativa não conta com poderes legislativos para esse fim. Mas as Juntas Comerciais têm dado aplicação à exigência ilegal, e somente admitem o arquivamento das alterações dos contratos sociais se ocorrer unanimidade, e, na falta desta, por maioria de capital somente quando o contrato social assim prever.

Quebrou-se, dessa forma, administrativamente, a imemorial norma imperante, advinda do direito marítimo, que estabelecia as democráticas deliberações dos sócios por maioria.

Ora, aplicando-se tal princípio aos contratos sociais antigos, que geralmente não previam, por despicienda, a forma de deliberação, 
pois a matéria estava resolvida em preceito legal, se tornou impossível a alteração do contrato por maioria do capital social. E os contratos que não previram a regra permissiva da alteração por votos majoritários não serão suscetíveis de alteração, a não ser por unanimidade. E a solução para o impasse é a dissolução social. Fica, assim, a sociedade comercial sujeita ao arbítrio de um sócio apenas, que detém o direito de veto, quando está em jogo o interesse da maioria na alteração do contrato, muitas vezes de necessidade vital para a sociedade comercial. O princípio, como se vê, é flagrantemente antidemocrático, pois sujeita a maioria à vontade discricionária da minoria.

Face ao exposto, divergimos da orientação do Anteprojeto de 1972 de Código Civil (art. 1.060) hoje art. 1.036 do Projeto, quando estabelece para a alteração dos elementos do contrato social, como o nome, o objeto, a sede, a duração da sociedade, o capital, a indicação do gerente etc., que a deliberação seja unânime, admitindo, porém, para as demais modificaçeõs, a maioria absoluta de votos, se o contrato não determinar a necessidade de deliberação por unanimidade.

O sistema do Código vigente, repetimos, é perfeito, não havendo nenhum motivo e interesse do comércio em vê-lo modificado. As inovações administrativas, que não têm valor jurídico e podem ter a sua validade contestada perante o Poder Judiciário são, de fato, perniciosas e altamente danosas para os interesses das sociedades comerciais de pessoas, ainda mais quando se continua a admitir a alteração dos estatutos das sociedades anônimas por maioria, a não ser em casos muito restritos em que se exige a unanimidade (art$105)^{\prime \prime}$.

Com efeito, alguma das disposições contratuais só devem poder ser alteradas por unanimidade, e assim é também nas sociedades anônimas. O objeto da sociedade, a mudança de nacionalidade, são pontos fundamentais e essenciais que podem desinteressar um sócio pela sociedade; requer tais modificações o concurso da unânimidade dos sócios.

O Projeto, no art. 1.036, exagera o elenco de cláusulas que são inalteráveis no contrato social por maioria dos sócios. Vale reproduzir o art. 1.036:

"As modificações do contrato social, que tenham por objeto matéria indicada no art. 1.034, dependem do cosentimento de todos os sócios; as demais podem ser decididas por maioria absoluta de votos, se o contrato não determinar a necessidade de deliberação unânime". 
Quais são as matérias indicadas no art. 1.034? São as cláusulas componentes do contrato, do ato constitutivo da sociedade, a saber:

"I - o nome, nacionalidade, estado civil, profissão e residência dos sócios, se pessoas físicas, e a firma ou a denominação, nacionalidade e sede dos sócios, se jurídicas".

Ora, conforme a regra do art. 1.036, a retirada de um sócio pode ser vetada por um outro, desde que apenas se recuse a admi. tí-la, negando-se a alterar o contrato...

“II - A denominação, o objeto, a sede e o prazo da sociedade".

Estamos de acordo que o objeto, como a naconialidade, sejam destacados como imutáveis pela maioria, requerendo a unanimidade de sócio. O investimento do sócio no capital da sociedade é determinado, evidentemente, pelo objetivo social, que the merece interesse. A mudança desse objeto pode desinteressa-lo, inclusive pelos riscos serem maiores. Mas a denominação, a sede e o prazo da sociedade devem ser possíveis com a simples maioria.

"III - O capital da sociedade, expresso em moeda corrente, podendo compreender qualquer espécie de bens, suscetíveis de avaliação pecuniária".

Temos assistido casos incriveis em matéria de divergência entre os sócios, com perniciosas repercussões na sociedade.

Basta que um deles se recuse a alterar o contrato social, para aumento do capital, para que a sociedade fique estagnada e se estiole por falta inclusive de capital de giro. Outras vezes o sócio divergente se recusa a assinar alteração de contrato social para corrigir o capital, segundo a reavaliação do ativo. Agindo assim, o sócio divergente se torna um ditador na sociedade, obrigando a dissolução da mesma. Essa imutabilidade do cãpital, por maioria, tem dado azo a verdadeiras chantagens da minoria. E todos estão de acôrdo, nesta Casa que as ditaduras são condenáveis, sobretudo a ditadura das minorias, que é odiosa.

Os outros itens do art. 1.034, merecem iguais observações, mas, para finalizar, pomos em destaque o inciso VI - isto é, a indicação das "pessoas físicas incumbidas da administração da sociedade, e seus poderes e atribuições". 
Ora, no ato de constituição da sociedade todos os sócios estão num "mar de rosas". O Prof. Miguel Rale, num brilhante Parecer, bem nos recordamos, diz que no ato da constituição da sociedade os sócios estão como nubentes em "lua de mel", mas as divergências surgem geralmente, em seguida, no convívio diário. Assim também nas sociedades.

Se um sócio nomeado no contrato social decair da confiança dos demais, e não puder ser substituido por maioria, então a única solução será a disolução, a morte da sociedade. A unanimidade será impossível, pois ele terá também direito a voto. E a dissolução da empresa é um ato anti-social que deve ao máximo das possibilidades ser evitado.

8.10 - A menoridade. (Art. 5. ${ }^{\circ}$ ). Por um conservadorismo que não compreendemos nos tempos modernos, o Projeto mantém o término da menoridade aos 21 anos. Diz esse preceito:

"Aos vinte e um anos completos acaba a menoridade, ficando habilitado o indivíduo para todos os atos da vida civil".

Esperavamos, sinceramente, que por fim a Comissão Revisora admitisse, já que o Projeto era construido sob o signo da unificação, e por via de consequência da uniformização, que a menoridade cessasse aos 18 anos, como vem ocorrendo em outros países.

Ora, não há argumento lógico que nos convença que o menor possa, como eleitor, escolher o Presidente da República, Governadores, Senadores e Deputados; que seja convocado para o Serviço Militar, podendo ir à guerra; adquira capacidade se se estabelecer com economia própria; ser imputado criminalmente; e habilitar-se como motorista, não possa adquirir, por exemplo, por ser menor relativamente incapaz, um pequeno imóvel ou contrair núpcias sem autorização paterna.

$\mathrm{Na}$ sociedade moderna o menor de vinte e um anos e maior de dezoito anos, psíquica e biologicamente, adquire a plenitude de sua capacidade física, intelectual e moral. A nosso ver não há motivos para que o Projeto não antecipe a maioridade para os dezoito anos, simplificando toda a matéria, inclusive quanto a capacidade de ser empresário.

8.11 - O neologismo jurídico "Atividade Negocial". Tendo proscrito, como tivemos oportunidade de anotar anteriormente, as palavras "comercial" ou "mercantil", como se fossem expressões pornográficas... o Projeto teve necessidade de, arbitrariamente, criar 
- neologismo jurídico para substituir aquelas expressões. Daí surgiu a "Atividade Negocial", que dá título ao II livro, da Parte Especial.

Atividade Negocial nada mais é do que a atividade comercial, pois ao tratar da empresa, conceituando-a, o Projeto excluiu, dessa figura, a atividade civil, como a intelectual, científica, literária ou artística (art. 1.003, parágrafo único), e o empresário rural. Regula as sociedades em geral, transpondo, sem aclimatação, por artificiosismo, a sociedade simples, para não usar da expressão sociedade civil. Se usasse esta expressão, por força teria que lançar mão da nomenclatura de sociedade comercial.

Analisando, mais de perto, a expressão atividade negocial, sob os padrões da teoria jurídica pura, veríamos que atividade negocial é a prática constanie de negócios jurídicos. E do negócio jurídico - Código trata no Livro Terceiro, da Parte Geral.

Ora, a doutrına nos ensina que os negócios jurídicos constituem o meio mais comum de aquisição de direitos. Mas a "atividade negocial", na linguagem inventada pelo Projeto, não é a atividade comum de aquisição de direitos, mas o exercício da empresa...

Assim, a expressão "atividade negocial", na acepção usada no Projeto, é vazia de sentido etimológico e jurídico.

Merece, pois ser banida. Reponha-se no Livro II, da Parte Especial, o título mais correto usado pelo antigo Projeto de Código de Obrigações de 1965: "Dos empresários e das sociedades".

Nosso arsenal de expressões jurídicas já é por demais complexo para que se venha a ter o luxo de inventar, desmotivadamente, novas expressões.

\section{Senhor Presidente e}

Senhores Deputados.

Pedimos, da benevolência democrática de V. Excias., absolvição pelo enfado que lhes causamos, na exposição de nossas objeções a alguns preceitos do Projeto de Código Civil.

Com certa ênfase, algumas vezes, devemos ter alterado a voz ou apertado a pena, na contestação de certos preceitos do Projeto: esta veemência, entretanto, é natural nos estudos doutrinários e científicos quando com eles nos empolgamos. Mas, com tudo isso, porém, pretendemos não agredir o Projeto na sua magestade, mas açular a consciência jurídica e democrática de V. Excias., para o fato de que não se pode nem se deve elaborar legislação de tal magni- 
tude de afogadilho, superficialmente, com a angústia dos prazos fatais.

Não imaginam V. Excias. a preocupação que se acumula nas Universidades, nas Corporações de Classe, na Ordem dos Advogados e nos Institutos de Advogados, no meio da imprensa, enfim, em toda a Nação brasileira, para com o perigo da elaboração urgente - urgentíssima do novo Código Civil. O prazo de trinta dias que essa Comissão concedeu para a apresentação de emendas, mal nos deu o tempo de, acuradamente, ler os primeiros livros do Projeto. Nossa experiência pessoal foi dolorosa. Ocupamos todo o mês de julho, dedicado às férias escolares, para elaborar estas observações.

Temos a consciência de que não esgotamos a matéria, muito, mas muito mesmo, poderíamos apresentar, se não estivessemos espicaçados pela exiguidade do prazo.

V. Excias. prestariam um enorme serviço ao Direito brasileiro, se dilatassem os prazos de tramitação do Projeto, para dar a todos nós novas oportunidades de análise.

Confiamos que o Congresso Nacional não decepcionará a Nação brasileira e a nossa História, dando a todos nós um diploma legal que não deslustre a memória augusta de Rui e de Clóvis.

Obrigado. 